\title{
Quantitative translation of microfluidic transporter in vitro data to in vivo reveals impaired albumin-facilitated indoxyl sulfate secretion in chronic kidney disease
} DOI:

10.1021/acs.molpharmaceut.9b00681

\section{Document Version}

Accepted author manuscript

Link to publication record in Manchester Research Explorer

Citation for published version (APA):

Van Der Made, T. K., Fedecostante, M., Scotcher, D., Rostami-hodjegan, A., Sastre Torano, J., Middel, I., Koster, A. S., Gerritsen, K. G., Jankowski, V., Jankowski, J., Hoenderop, J. G. J., Masereeuw, R., \& Galetin, A. (2019). Quantitative translation of microfluidic transporter in vitro data to in vivo reveals impaired albumin-facilitated indoxyl sulfate secretion in chronic kidney disease. Molecular Pharmaceutics, 16(11), 4551-4562.

https://doi.org/10.1021/acs.molpharmaceut.9b00681

Published in:

Molecular Pharmaceutics

\section{Citing this paper}

Please note that where the full-text provided on Manchester Research Explorer is the Author Accepted Manuscript or Proof version this may differ from the final Published version. If citing, it is advised that you check and use the publisher's definitive version.

\section{General rights}

Copyright and moral rights for the publications made accessible in the Research Explorer are retained by the authors and/or other copyright owners and it is a condition of accessing publications that users recognise and abide by the legal requirements associated with these rights.

Takedown policy

If you believe that this document breaches copyright please refer to the University of Manchester's Takedown Procedures [http://man.ac.uk/04Y6Bo] or contact uml.scholarlycommunications@manchester.ac.uk providing relevant details, so we can investigate your claim.

\section{OPEN ACCESS}




\title{
Quantitative translation of microfluidic transporter in vitro data to in vivo reveals impaired albumin-facilitated indoxyl sulfate secretion in chronic kidney disease
}

Thomas K van der Made, Michele Fedecostante, Daniel Scotcher, Amin Rostami-Hodjegan, Javier Sastre Torano, Igor Middel, Andries S Koster, Karin G Gerritsen, Vera Jankowski, Joachim Jankowski, Joost G. J. Hoenderop, Rosalinde Masereeuw, and Aleksandra Galetin

\author{
Mol. Pharmaceutics, Just Accepted Manuscript • DOI: 10.1021/ \\ acs.molpharmaceut.9b00681 • Publication Date (Web): 16 Sep 2019
}

Downloaded from pubs.acs.org on September 26, 2019

\section{Just Accepted}

"Just Accepted" manuscripts have been peer-reviewed and accepted for publication. They are posted online prior to technical editing, formatting for publication and author proofing. The American Chemical Society provides "Just Accepted" as a service to the research community to expedite the dissemination of scientific material as soon as possible after acceptance. "Just Accepted" manuscripts appear in full in PDF format accompanied by an HTML abstract. "Just Accepted" manuscripts have been fully peer reviewed, but should not be considered the official version of record. They are citable by the Digital Object Identifier (DOI®). "Just Accepted" is an optional service offered to authors. Therefore, the "Just Accepted" Web site may not include all articles that will be published in the journal. After a manuscript is technically edited and formatted, it will be removed from the "Just Accepted" Web site and published as an ASAP article. Note that technical editing may introduce minor changes to the manuscript text and/or graphics which could affect content, and all legal disclaimers and ethical guidelines that apply to the journal pertain. ACS cannot be held responsible for errors or consequences arising from the use of information contained in these "Just Accepted" manuscripts. 
Albumin-facilitated indoxyl sulfate uptake via OAT1

\section{Quantitative translation of microfluidic transporter in vitro data to in vivo reveals impaired albumin-facilitated indoxyl sulfate secretion in chronic kidney disease}

Thomas K. van der Made ${ }^{1}$, Michele Fedecostante ${ }^{2}$, Daniel Scotcher ${ }^{1}$, Amin Rostami- Hodjegan ${ }^{1,3}$, Javier Sastre Toraño ${ }^{4}$, Igor Middel$^{2}$, Andries S. Koster ${ }^{2}$, Karin G. Gerritsen ${ }^{5}$, Vera Jankowski ${ }^{6}$, Joachim Jankowski ${ }^{6,7}$, Joost G. J. Hoenderop ${ }^{8}$, Rosalinde Masereeuw ${ }^{2,9^{*}}$ and Aleksandra Galetin ${ }^{1,9^{*}}$

${ }^{1}$ Centre for Applied Pharmacokinetic Research, School of Health Sciences, The University of Manchester, UK

2Division of Pharmacology, Utrecht Institute for Pharmaceutical Sciences, Utrecht University, Utrecht, the Netherlands

${ }^{3}$ Simcyp Division, Certara UK Limited, Sheffield, UK

${ }^{4}$ Department of Chemical Biology and Drug Discovery, Utrecht Institute for Pharmaceutical Sciences, Utrecht University, Utrecht, The Netherlands

${ }^{5}$ Department of Nephrology and Hypertension, University Medical Center Utrecht, Utrecht, The Netherlands.

${ }^{6}$ RWTH Aachen University Hospital, Institute for Molecular Cardiovascular Research, Aachen, Germany

${ }^{7}$ School for Cardiovascular Diseases, Maastricht University, Universiteitssingel 50, Maastricht, The Netherlands

${ }^{8}$ Department of Physiology, Radboud Institute for Molecular Life Sciences, Radboud University Medical Center, Nijmegen, The Netherlands

${ }^{9}$ These senior authors contributed equally to this work

\section{*Corresponding authors}

Aleksandra Galetin, PhD, Centre for Applied Pharmacokinetic Research, Division of Pharmacy and Optometry, School of Health Sciences, Faculty of Biology Medicine and Health, The University of Manchester, UK 
Albumin-facilitated indoxyl sulfate uptake via OAT1

R. Masereeuw, PhD, Faculty of Science, Department of Pharmaceutical Sciences, Universiteitsweg 99 (room 2.72), 3584 CG Utrecht, the Netherlands

\section{Word Count}

Abstract \# 271

Introduction \# 631

Methods (with equations) \# 1683

Results \# 920

Discussion \# 1280

Total \# 4514 (excluding abstract, figure/table captions/text and footnotes)

Tables \# 6

Figures \# 3

Supplementary Tables \# 3

Supplementary Figures \# 2

Supplementary Methods \# 1 
Albumin-facilitated indoxyl sulfate uptake via OAT1

Abstract: Indoxyl sulfate (IxS), a highly albumin-bound uremic solute, accumulates in chronic kidney disease $(C K D)$ due to reduced renal clearance. This study was designed to specifically investigate the role of human serum albumin (HSA) in IxS handling via organic anion transporter 1 (OAT1) in a microfluidic system and subsequently apply quantitative translation of in vitro data to predict extent of change in IXS renal clearance in CKD stage IV relative to healthy. Conditionally immortalized human proximal tubule epithelial cells overexpressing OAT1 were incubated with IxS (5-200 $\mu \mathrm{M})$ in the HSAfree medium or the presence of either HSA or CKD-modified HSA. IxS uptake in the presence of HSA resulted in more than 20-fold decrease in OAT1 affinity $\left(\mathrm{K}_{\mathrm{m}, \mathrm{u}}\right)$ and 38-fold greater in vitro unbound intrinsic clearance $\left(\mathrm{CL}_{\mathrm{int}, \mathrm{u}}\right)$ vs. albumin-free condition. In the presence of $C K D$-modified albumin, $\mathrm{K}_{\mathrm{m}, \mathrm{u}}$ increased 4-fold and IxS $\mathrm{CL}_{\text {int,u }}$ decreased almost 7 -fold relative to HSA. Fold-change in parameters exceeded differences in IxS binding between albumin conditions, indicating additional mechanism and facilitating role of albumin in IxS OAT-mediated uptake. Quantitative translation of IxS in vitro OAT1mediated $\mathrm{CL}_{\text {int,u }}$ predicted $60 \%$ decrease in IxS renal elimination as a result of $\mathrm{CKD}$, in agreement with the observed data (80\%). The findings of the current study emphasize the role of albumin in IxS transport via OAT1 and explored the impact of modifications in albumin on renal excretion via active secretion in CKD. For the first time, this study performed quantitative translation of transporter kinetic data generated in a novel microfluidic in vitro system to a clinically relevant setting. Knowledge gaps and future directions in quantitative translation of renal drug disposition from microphysiological systems are discussed.

\section{KEYWORDS}

indoxyl sulfate; OAT1; proximal tubule; in vitro-in vivo extrapolation; CKD

\section{GRAPHICAL ABSTRACT/ FOR TABLE OF CONTENTS USE ONLY}

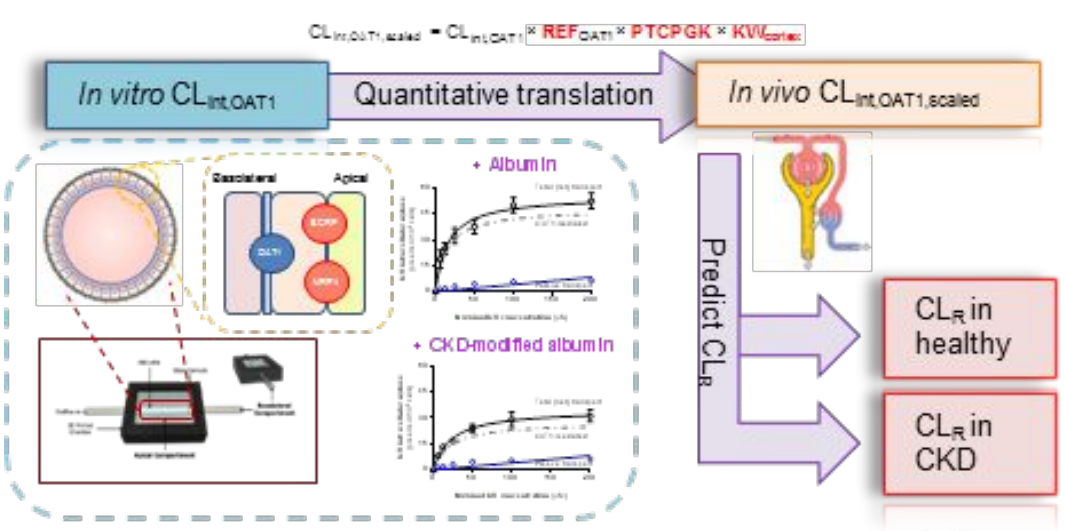


Albumin-facilitated indoxyl sulfate uptake via OAT1

\section{INTRODUCTION}

Chronic kidney disease (CKD) is a global health care problem, affecting approximately $12 \%$ of the population worldwide, with a prevalence of around $6.5 \%$ in advanced CKD stages III-V. ${ }^{1,2}$ CKD results in the accumulation of uremic solutes in plasma, especially protein-bound toxins secreted by renal drug transporters. ${ }^{3}$ One of the most prevalent accumulated solutes is indoxyl sulfate (IxS), implicated as a contributor to cardiovascular disease ${ }^{4}$ and renal disease progression. ${ }^{5}$ The underlying mechanisms causing reduced renal plasma excretion clearance $\left(C_{R}\right)$ and accumulation of IxS (also of drugs given to CKD patients) are still not fully elucidated. Intact nephron hypothesis proposes that the number of functional nephrons is decreased in CKD and that GFR and residual tubular function decrease in parallel. ${ }^{6}$ When tubular secretion is the dominant route of uremic toxin/drug elimination, impaired active secretion via renal drug transporters associated with CKD is expected to contribute significantly to reduced $\mathrm{CL}_{\mathrm{R}} \cdot{ }^{3,7}$

IxS is actively secreted via basolaterally expressed Organic Anion Transporters (OAT) 1 and, to a lesser extent, OAT3,8-11 paired with efflux via MRP4, BCRP and OAT4 transporters at the apical proximal tubule membrane. ${ }^{12,13}$ In plasma of healthy subjects, this uremic solute is $>90 \%$ bound to human serum albumin (HSA), with minimal binding to other plasma proteins. ${ }^{14}$ In CKD, the extent of IXS binding to albumin is reduced and this is attributed not only to changes in albumin concentrations, but also competition for albumin binding site and potentially posttranslational modifications of the protein. ${ }^{15-17}$ In healthy subjects, mean total and free IxS concentrations range from 0.4-0.9 mg/L (1.9$4.2 \mu \mathrm{M})$ and $0.02-0.03 \mathrm{mg} / \mathrm{L}(0.09-0.13 \mu \mathrm{M})$, respectively (Table S1). In advanced CKD (stage IV+), both total (average $24 \mathrm{mg} / \mathrm{L} ; 113 \mu \mathrm{M}$ ) and free (average $2.4 \mathrm{mg} / \mathrm{L} ; 11.3 \mu \mathrm{M}$ ) IxS concentrations increase (Table S1).

Considering all these changes in CKD, it is important to delineate the role of albumin in tubular secretion of IxS, in particular considering proposed albumin-facilitated active transport via OATs. ${ }^{11,18}$ Jansen et al. recently developed a microfluidic system wherein human conditionally immortalized proximal tubule epithelial cells (ciPTEC) were seeded on a hollow fiber membrane. ${ }^{11,} 19$ Use of microfluidic system and ability to investigate transepithelial transport is envisaged to improve mechanistic characterization in vitro of the complex interplay between multiple processes affecting 
Albumin-facilitated indoxyl sulfate uptake via OAT1

renal drug disposition, namely basolateral and apical uptake and efflux transporters, passive diffusion and tubular reabsorption. Other advantages of this microfluidic system include recapitulation of the extracellular environment, cell-to-medium ratio, tubule formation and removal of waste metabolites.

Quantitative translation of transporter data generated in vitro to in vivo is often done using physiologically-based pharmacokinetic modelling (PBPK). ${ }^{20-23}$ In vitro-in vivo extrapolation (IVIVE) of transporter kinetic data accounts for differences in expression of drug transporters and/or activity between the cellular system and in vivo. ${ }^{22,}{ }^{24}$ Although well-established for a number of cellular systems $^{25}$, translational ability of data from novel microphysiological systems ${ }^{26,27}$ is yet to be ascertained

There is an increasing interest to use IVIVE-based PBPK models to support dosage adjustments recommendations in product labelling for specific populations. ${ }^{22,}$ 28-30 However, examples where PBPK modelling was used to explore implications of different underlying disease mechanisms on predicted drug pharmacokinetics are still sparse. In the case of renal impairment, physiological kidney models have investigated the impact of reduced proximal tubule cellularity and reduced transporter expression, in conjunction with well-defined changes in GFR and plasma protein binding, on the predicted $C L_{R}$ of selected drugs. ${ }^{31-33}$

This study aimed to understand the role of albumin in IXS renal secretion via OAT1 in both healthy population and in advanced stage of CKD. To that end, IxS tubular secretion in the microfluidic system was investigated under different albumin conditions in vitro and quantitatively translated to in vivo; the predicted extent of change in $\mathrm{IXS} C \mathrm{~L}_{\mathrm{R}}$ in $\mathrm{CKD}$ relative to healthy was compared with reported clinical data. 
Albumin-facilitated indoxyl sulfate uptake via OAT1

\section{EXPERIMENTAL SECTION}

Chemicals and Materials. All chemicals and HSA were purchased from Sigma-Aldrich (Zwijndrecht, The Netherlands). MicroPESTM TF10 hollow fiber capillary membrane (wall thickness $100 \pm 25 \mu \mathrm{m}$, inner diameter $300 \pm 40 \mu \mathrm{m}$, max pore size $0.5 \pm 0.1 \mu \mathrm{m}$ ) was purchased from $3 \mathrm{M}-$ Membrana GmbH (Wuppertal, Germany). CKD-modified HSA has undergone post-translational modifications by guanidinylation reflecting changes occurring in CKD patients, as described previously. ${ }^{15}$

Uptake of indoxyl sulfate by ciPTEC-OAT1 in microfluidic system. CiPTEC with stable overexpression of OAT1 (ciPTEC-OAT1), ${ }^{34}$ were cultured in supplemented PTEC media under static conditions before seeding (between passage number 29-43). ${ }^{35}$ Hollow fiber capillary membrane was coated with L-DOPA and collagen type IV and seeded ( $1.5 \times 10^{6}$ cells), analogous to previous protocol. ${ }^{19}$

ciPTEC-OAT1 cells were exposed to a range of IxS concentrations $(5-200 \mu \mathrm{M})$ in the microfluidic system (detailed information on system has been reported previously) ${ }^{19}$ for 5 min at a flow rate of 6 $\mathrm{mL} . \mathrm{h}^{-1}$. IxS was dissolved in Kreb-Henseleit Buffer (supplemented with $10 \mathrm{mM}$ Hepes, $\mathrm{pH}=7.4$ ) and uptake was performed in the presence and absence of potent OAT inhibitor probenecid $(500 \mu \mathrm{M})$. Efflux transporter activity (e.g., BCRP and MRP4) was inhibited by addition of inhibitors (KO143 and MK571, $5 \mu \mathrm{M})$ in the apical compartment. Active uptake of IxS was investigated under three conditions, namely in albumin-free medium, with HSA at $1 \mathrm{mM}$ (corresponding to a physiological plasma albumin concentration in humans, $35-50 \mathrm{~g} / \mathrm{L}),{ }^{11}$ and in the presence of CKD-modified HSA at $1 \mathrm{mM}$. Uptake was terminated by addition of ice-cold Kreb-Henseleit Buffer. The buffer was removed and cells were lysed with $250 \mu \mathrm{L}$ of $0.1 \mathrm{M} \mathrm{NaOH}$ for $15 \mathrm{~min}$. Subsequently, intracellular concentrations of IxS were quantified by liquid chromatography tandem mass spectrometry (LC-MS/MS; Supplementary Methods). The IxS fraction unbound in incubation media ( $\mathrm{fu}_{\mathrm{med}}$ ) was determined by measuring IXS free and bound fractions using ultrafiltration over the concentration range tested, as described previously. ${ }^{11,15}$

Transepithelial transport studies. CiPTEC-OAT1 cells in the microfluidic system were perfused with uremic plasma (measured IXS concentration of $282 \pm 4 \mu \mathrm{M}$ ) or healthy plasma (spiked with $282 \mu \mathrm{M}$ 
Albumin-facilitated indoxyl sulfate uptake via OAT1

IxS) for $10 \mathrm{~min}$ in the presence or absence of probenecid $(500 \mu \mathrm{M})$. After perfusion, fluid in the apical compartment was collected and IxS was quantified by LC-MS/MS (Supplemental methods). Cell viability (Prestoblue cell viability assay) and barrier integrity (inulin-FITC leakage) assays were performed using cisplatin $(200 \mu \mathrm{M})$ as a positive control. Cisplatin was used as positive control as it is known to be toxic to kidney cells and disrupts membrane barrier integrity. Pooled uremic and healthy plasma from subjects were obtained from the Department of Nephrology and Hypertension, University Medical Center Utrecht, Utrecht, The Netherlands.

Data analysis. IxS uptake rates (pmol/min $/ 10^{6}$ cells) in the presence and absence of probenecid were calculated by normalising measured uptake amounts for incubation time, assuming linearity with respect to time and fibre cellularity (details on determination of the cell number in Table S2). Passive transport was determined assuming that probenecid $(500 \mu \mathrm{M})$ completely inhibited uptake via OAT1. OAT1-mediated uptake rate $\left(\mathrm{pmol} / \mathrm{min} / 10^{6}\right.$ cells) at specific $\mathrm{IxS}$ concentration was calculated as a difference between total and passive transport rates.

The Michaelis constant defining OAT1 binding affinity $\left(\mathrm{K}_{\mathrm{m}} ; \mu \mathrm{M}\right)$ and maximum uptake rate $\left(\mathrm{V}_{\max }\right.$; $\mathrm{pmol} / \mathrm{min} / 10^{6}$ cells) were estimated, by fitting the Michaelis-Menten equation (eq.1) to OAT1-mediated uptake rates and nominal IxS concentrations using Graphpad Prism 7.04 (La Jolla California USA). IxS fumed was calculated as the slope of the linear regression of the nominal versus free IxS concentration (Figure S1). Subsequently, the $\mathrm{K}_{\mathrm{m}}$ corrected for binding $\left(\mathrm{K}_{\mathrm{m}, \mathrm{u}}\right)$ and in vitro unbound intrinsic clearance $\left(\mathrm{CL}_{\text {int,u }}\right)$ expressed in $\mu \mathrm{L} / \mathrm{min} / 10^{6}$ cells were calculated (eq. 2 and eq. 3 ).

$$
\begin{aligned}
& \mathrm{v}=\frac{\mathrm{V}_{\max } \times[S]}{\mathrm{K}_{\mathrm{m}}+[\mathrm{S}]} \\
& \mathrm{K}_{\mathrm{m}, \mathrm{u}}=\mathrm{K}_{\mathrm{m}} \times f \mathrm{fu}_{\mathrm{med}} \\
& \mathrm{CL}_{\text {int,u }}=\frac{\mathrm{V}_{\max }}{\mathrm{K}_{\mathrm{m}, \mathrm{u}}}
\end{aligned}
$$

Quantitative translation of in vitro unbound intrinsic clearance to in vivo. IVIVE was performed by applying physiological scaling factors, ${ }^{36}$ to translate in vitro IxS kinetic data obtained in a microfluidic system to an organ level (eq. 4, Figure 1). 
Albumin-facilitated indoxyl sulfate uptake via OAT1

$\mathrm{CL}^{\text {int,u,scaled }}=\mathrm{CL}_{\text {int,u }}\left[\frac{\mu \mathrm{L} \cdot \mathrm{min}^{-1}}{10^{6} \text { cells }}\right] \times \mathbf{R E F}$ OAT1 $\left[\frac{\frac{\text { pmolTransporter PTC }}{10^{6} \text { PTC }}}{\frac{\text { pmolTransporter system }}{10^{6} \text { cells of system }}}\right] \times \mathbf{P T C P G K}\left[\frac{10^{6} \mathrm{PTC}}{\mathrm{g} \text { Kidney }}\right] \times \mathbf{K W}_{\text {cortex }}[\mathrm{g}$ kidney $]$

$\mathrm{CL}_{\text {int,u }}$ is derived from in vitro IxS uptake studies and reflects OAT1-mediated IxS uptake, whereas $\mathrm{CL}_{\text {int,u,scaled }}$ represents the scaled in vivo unbound OAT1-mediated intrinsic clearance, assuming that uptake via OAT1 is the rate-determining step in IxS renal disposition. $\mathrm{REF}_{\mathrm{OAT} 1}$ is relative expression factor for OAT1 (dimensionless) and accounts for differences in transporter expression between different systems. Due to the lack of data on OAT1 expression in ciPTEC in the microfluidic system, $\mathrm{REF}_{\mathrm{OAT} 1}$ value of 1 was applied assuming no difference in OAT1 expression between in vitro and in vivo, as done previously. ${ }^{31}$ PTCPGK (number of proximal tubule cells/g kidney) allows the extrapolation of in vitro data to per $\mathrm{g}$ of kidney. ${ }^{25,}{ }^{36} \mathrm{~A}$ mean value of 60 million of proximal tubule cells/g kidney was based on previous simulation studies. ${ }^{32,36}$ Ratio between ciPTEC cellularity and primary proximal tubule cells was assumed to be 1 , as used before for HEK293 cells. ${ }^{36}$ Final scaling factor (cortex kidney weight, $\mathrm{KW}_{\text {cortex }}$ ) extrapolates active clearance value to both kidneys; focus was on cortex as proximal tubule cells exclusively reside in this region. Considering uncertainty in some of the scaling factors, sensitivity analysis was performed by varying REF OAT1 $_{1}$ and PTCPGK in the model for healthy subjects to assess the impact on predicted IxS $C L_{R}$.

In the case of advanced CKD (stage IV), quantitative translational approach followed the same principles as above for healthy; known changes in physiological parameters (e.g., GFR, fup) associated with the disease were considered (Table 1). Scaling factors (PTCPGK, REF OAT1 $_{1}$ ) were the same as in healthy population due to lack of quantitative data on cell number or transporter expression in CKD patients. Subsequently, impact of disease-related reduction in either transporter expression or PTCPGK on the predicted $\mathrm{CL}_{R}$ ratio was investigated. The implemented decrease in these physiological scaling factors was proportional to changes in GFR in CKD stage IV, based on intact nephron hypothesis and animal studies reporting proximal tubule cell damage, reduced kidney size and reduced OAT expression in disease. ${ }^{7,37-39}$ Model input values for the individual parameters are summarized in Table 1. 


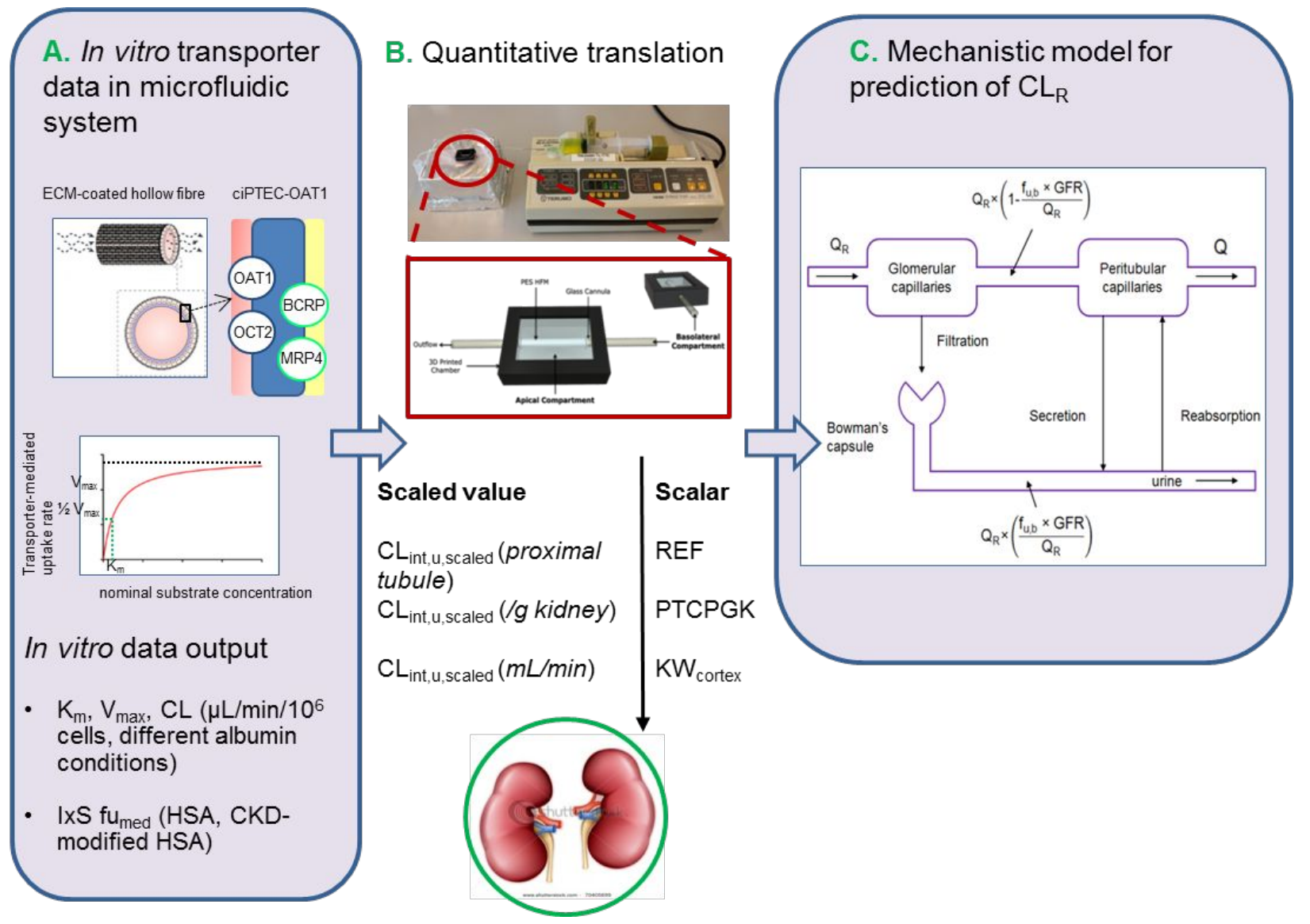

Figure 1. Quantitative translation of in vitro transporter kinetic data obtained in microfluidic system to predict renal plasma excretion clearance $\left(C_{L_{R}}\right)$. (A) Indoxyl sulfate (IxS) uptake was investigated in a microfluidic device with ciPTEC-OAT1 and in vitro unbound intrinsic clearance $\left(\mathrm{CL}_{\text {int,u }}\right)$ was determined. (B) $\mathrm{CL}_{\text {int,u }}$ was scaled with relative OAT1 expression factor $\left(\operatorname{REF}_{\mathrm{OAT1}}\right)$, the number of proximal tubule cells per gram of kidney (PTCPGK) and cortex kidney weight ( $\left.\mathrm{KW}_{\text {cortex }}\right)$ to predict in vivo unbound intrinsic clearance $\left(\mathrm{CL}_{\text {int,u,scaled }}\right)$. $(\mathbf{C})$ In order to predict renal plasma clearance $\left(\mathrm{CL}_{\mathrm{R}}\right)$ of IxS, other renal processes (glomerular filtration and tubular reabsorption) were also accounted for (Eq. 5). The filtration component is determined by the renal cortex blood flow $\left(Q_{R}\right)$, the glomerular filtration rate (GFR) and the fraction unbound of $\mathrm{IXS}\left(\mathrm{fu} \mathrm{u}_{\mathrm{p}}\right)$ in plasma. 
Prediction of indoxyl sulfate renal plasma excretion clearance. In order to predict total $I x S C_{R}$, three renal elimination mechanisms were considered, namely glomerular filtration, active secretion and tubular reabsorption, derived from Zamek-Gliszczynski et al. ${ }^{40}$ and adapted to estimate renal plasma clearance (eq. 5). ${ }^{41}$

$C L_{R}=\left[f u_{p} \times G F R+\left(1-\frac{f u_{p} \times G F R}{Q_{R}}\right) \times\left(\frac{Q_{R} \times f u_{p} \times C L_{\text {int,uscaled }}}{Q_{R}+\frac{f u_{p}}{R_{B} \cdot \mathrm{P}} \times C L_{\text {int,uscaled }}}\right)\right] \times\left(1-F_{\text {reab }}\right)(5)$

Where $Q_{R}$ is the renal cortex blood flow $(\mathrm{mL} / \mathrm{min}), \mathrm{CL}_{\text {int,u,scaled }}(\mathrm{mL} / \mathrm{min})$ is the in vivo unbound intrinsic clearance (defined in eq. 4), fup is fraction unbound in plasma and $F_{\text {reab }}$ is the fractional tubular reabsorption. $R_{B: P}$ is the IXS blood-to-plasma ratio and value of 0.55 (1-hematocrit) was applied due to lack of reported data. Eq. 5 can be expressed in terms of blood clearance, assuming equilibrium of unbound concentrations in plasma and blood. ${ }^{40}$

Relative contribution of active secretion to IxS $\mathrm{CL}_{R}$ was calculated (eq.6):

Relative contribution $(\%)=\left(1-\frac{\text { GFR } \times \text { fup }}{C L_{R}}\right) \times 100$ (6)

Contribution of tubular reabsorption was assumed to be negligible $\left(\mathrm{F}_{\text {reab }}=0\right)$. Potential involvement of OAT4 as apical uptake transporter was not considered in this study. Eq. 5 was used for healthy and in case of CKD changes in physiological parameters associated with CKD were considered (Table 1). Although reported differences in hematocrit levels between healthy and CKD ${ }^{42}$ were accounted for, these had no impact on the predicted $C L_{R}$ value.

Collation of indoxyl sulfate clinical data in healthy and CKD population. Predicted IxS $C L_{R}$ was compared to reported clinical data in order to validate the predictive performance and translational ability of the in vitro data generated in the current study. Pubmed was searched for clinical studies reporting (unbound) $\mathrm{CL}_{R}$ of IxS in healthy subjects and in patients with varying stages of $\mathrm{CKD}$ (Results section Table 4). Clinical studies with end stage renal disease, hemodialysis or peritoneal dialysis patients were excluded from the analysis unless IxS free and total levels were determined before dialysis. Table 3 and S1 give an overview of clinical studies (after 2012) reporting total and/or free IXS concentrations in healthy subjects and CKD patients. ${ }^{43}$ The fu value from Rossi et al. ${ }^{44}$ for CKD stage IV was used as input in the $\mathrm{CL}_{R}$ prediction model since the study reported values per specific CKD stage. 
Albumin-facilitated indoxyl sulfate uptake via OAT1

Table 1. Information on scaling factors used to predict in vivo unbound OAT1-mediated intrinsic clearance $\left(\mathrm{CL}_{\text {int,u,scaled }}\right)$ and indoxyl sulfate renal plasma excretion clearance (IxS $\left.C_{R}\right)$. The reported numbers are based on physiological values (e.g. PTCPGK, $K W_{\text {cortex }}, Q_{R}$ and $f u_{p}$ ), experimental values (ciPTEC number and $\mathrm{CL}_{\text {int,u }}$ ) or were assumed due to lack of clinical and/or experimental evidence $\left(R E F_{\mathrm{OAT} 1}, \mathrm{~B} / \mathrm{P}\right.$ and $\left.\mathrm{F}_{\text {reab }}\right)$. Differences in individual parameters in healthy subjects and CKD patients were taken into account if clinical evidence was available.

\begin{tabular}{|c|c|c|c|}
\hline & Healthy subjects & CKD stage IV & Reference \\
\hline \multicolumn{4}{|l|}{ IVIVE Scaling factors } \\
\hline $\mathrm{REF}_{\text {OAT1 }}$ & 1 (assumed) & 1 (assumed) $^{\mathrm{a}}$ & - \\
\hline $\begin{array}{l}\text { PTCPGK } \\
\text { (proximal tubule cells/g } \\
\text { kidney) }\end{array}$ & $\begin{array}{l}60 \times 10^{6} \\
\text { (range } 50-70 \times 10^{6} \text { ) }\end{array}$ & $60 \times 10^{6} \mathrm{a}$ & Neuhoff et al. ${ }^{36}$ \\
\hline $\begin{array}{l}\text { Kidney weight }(\mathrm{g}) \\
\text { (average left + right } \\
\text { kidney) }\end{array}$ & 249 & $249^{a}$ & $\begin{array}{l}\text { Molina et al. } 45,46 \text { and taking } \\
\text { into account male/female ratio } \\
\text { in study by Poesen et al. }{ }^{47}\end{array}$ \\
\hline $\mathbf{K} \mathbf{W}_{\text {cortex }}(\mathrm{g})$ & $\begin{array}{l}169 \\
\text { (68\% of kidney weight) }\end{array}$ & $\begin{array}{l}169 \\
\text { ( } 68 \% \text { of kidney } \\
\text { weight) }\end{array}$ & Scotcher et al. ${ }^{48}$ \\
\hline \multicolumn{4}{|c|}{ Input in the static model to predict IXS $C L_{R}$} \\
\hline $\mathbf{Q}_{\mathbf{R}}(\mathrm{mL} / \mathrm{min})$ & 1008 & 585 & $\begin{array}{l}\text { Scotcher et al. } 48 \text { and } 42 \% \\
\text { reduction in advanced CKD } \\
\text { patients (Table S3) }\end{array}$ \\
\hline $\begin{array}{l}\text { GFR }(\mathrm{mL} / \mathrm{min}) \\
\text { (defined GFR } \\
\text { category) }\end{array}$ & $105(90-120)$ & $22.5(15-30)$ & CKD work group 49 \\
\hline$f u_{p}$ & 0.025 & 0.06 & Rossi et al. ${ }^{44}$ \\
\hline $\mathbf{R}_{\mathrm{B}: \mathbf{P}}$ & $\begin{array}{l}0.55 \text { (1-hematocrit, } \\
\text { assumed) }\end{array}$ & $\begin{array}{l}0.66 \text { (1-hematocrit, } \\
\text { assumed) }\end{array}$ & $\begin{array}{l}\text { Rowland Yeo et al. }{ }^{42} \text { and } \\
\text { taking into account } \\
\text { male/female proportionality in } \\
\text { study Poesen et al. }{ }^{47}\end{array}$ \\
\hline$F_{\text {reab }}$ & 0 (assumed) & 0 (assumed) & - \\
\hline $\mathrm{CL}_{\text {int,u,scaled }}(\mathrm{mL} / \mathrm{min})$ & 342.5 & 52.0 & - \\
\hline
\end{tabular}

$\mathrm{a}=$ no quantitative information available on differences between healthy subjects and CKD patients for these parameters. 
Albumin-facilitated indoxyl sulfate uptake via OAT1

RESULTS

OAT1-mediated uptake of indoxyl sulfate in a microfluidic system +/- albumin. Concentrationdependent uptake of IxS by ciPTEC-OAT1 monolayers was observed in HSA-free medium; this trend was also evident in the presence of albumin (Figure 2, Table 2). Saturable uptake of IxS in HSA-free medium resulted in $\mathrm{K}_{\mathrm{m}}$ and $\mathrm{V}_{\max }$ of $29.3 \mu \mathrm{M}$ and $26.5 \mathrm{pmol} / \mathrm{min} / 10^{6}$ cells, respectively (Table 2). The IxS fu $\mathrm{fu}_{\text {med }}$ in the presence of HSA was 0.1 (Figure S1). Presence of HSA resulted in increased transporter affinity and 20 -fold lower $\mathrm{K}_{\mathrm{m}, \mathrm{u}}$ compared to albumin-free incubation media. In addition, presence of albumin increased the transporter $V_{\max }$ and as a result, the IxS OAT1-mediated $\mathrm{CL}_{\text {int,u }}$ increased by 37 -fold (Table 2). The inclusion of albumin did not have an impact on IxS passive diffusion (Figure 2).

OAT1-mediated uptake of indoxyl sulfate in the presence CKD-modified albumin. Concentration-dependent uptake of IxS in ciPTEC-OAT1 was observed in the presence of CKDmodified HSA (Figure 2, Table 2). Lower extent of IxS binding was apparent in the presence of CKDmodified HSA, with a fumed 0.26 relative to 0.1 in the HSA condition (Figure S1). Nearly 4 -fold lower affinity for OAT1 and reduced $V_{\max }$ in the presence of CKD-modified HSA (Table 2) resulted in 6.6-fold decrease in $\mathrm{CL}_{\text {int,u }}$ relative to HSA (Table 2). Passive diffusion between different albumin conditions was comparable (Figure 2).

Clinical studies reporting indoxyl sulfate fraction unbound in plasma in healthy subjects and CKD patients. Table 3 provides an overview of collated studies reporting IxS fu $\mathrm{u}_{\mathrm{p}}$, whereas all collated literature studies reporting total IxS concentrations in plasma are summarized in Table S1. High intraand inter-study variability in total and free IxS concentrations were apparent, in line with pre-2012 data reported by the uremic toxin workgroup (Table 3). ${ }^{43}$ One study reported fu $\mathrm{u}_{\mathrm{p}}$ values in various CKD stages and found a substantial increase in $f_{p}$ with increasing severity of the disease (from 0.03 to 0.16 in control to- stage $V$, respectively) ${ }^{44}$ 
IxS in cell lysate (intracellular uptake)

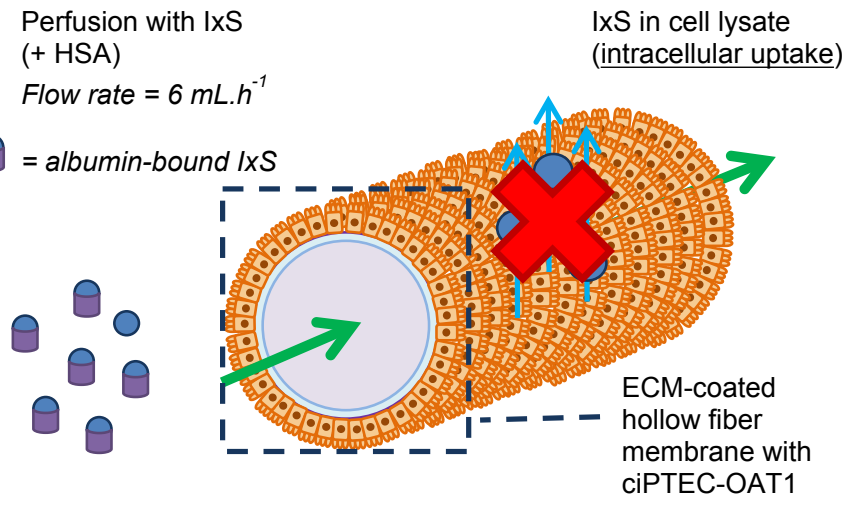

\section{HSA}

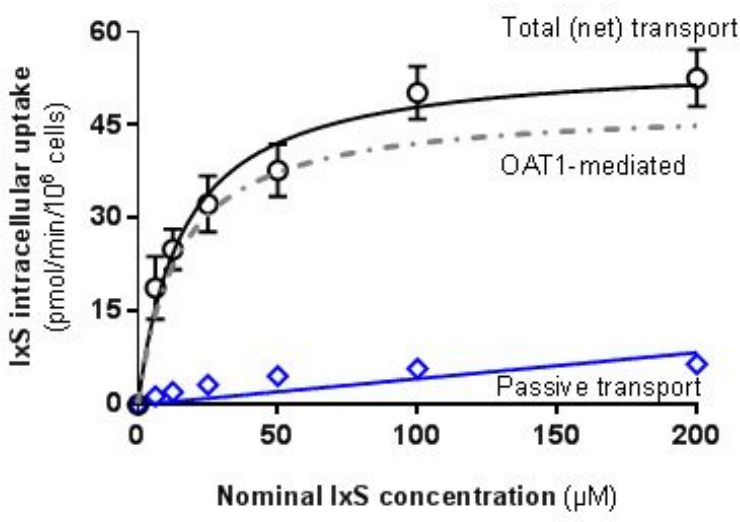

HSA-free

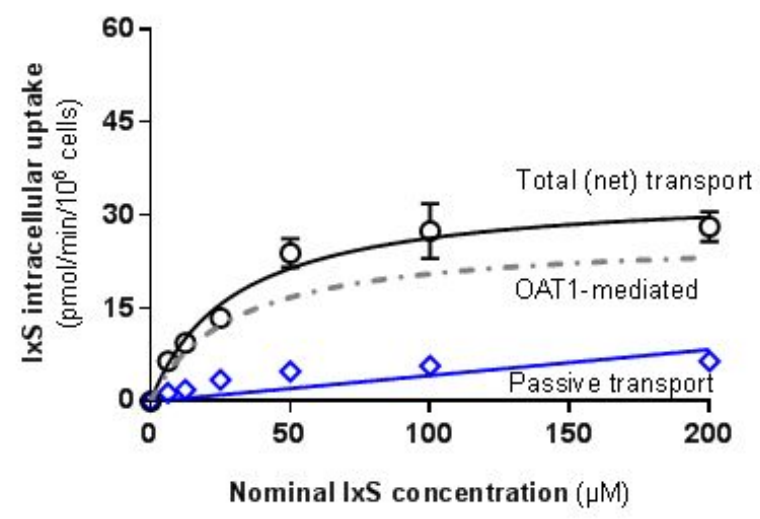

CKD-modified HSA

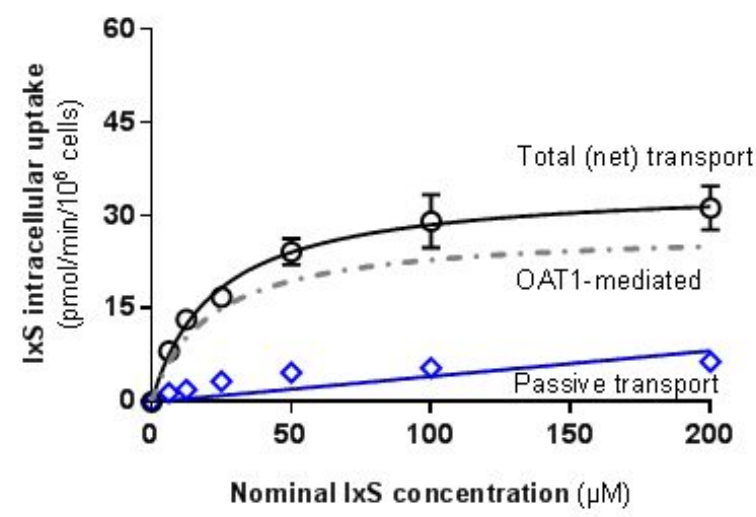

Figure 2. Indoxyl sulfate (IXS) uptake kinetics in ciPTEC-OAT1 seeded in microfluidic system in the absence or presence of human serum albumin (HSA) or CKD-modified albumin. ciPTECOAT1 cells were exposed to a range of IxS concentrations (5-200 $\mu \mathrm{M})$ in HSA-free incubation media (HSA-free), in the presence of $1 \mathrm{mM} \mathrm{HSA}$ (corresponding to healthy plasma) and in the presence of $1 \mathrm{mM}$ CKD-modified HSA. Top left panel illustrates the experimental design to determine intracellular IxS uptake; efflux transporter activity was inhibited by addition of inhibitor cocktail in the apical compartment $(E C M=$ extracellular matrix). Observed total transport (open black circle) and passive transport (open blue diamonds) are depicted. Fitted Michaelis-Menten equation to OAT1-mediated transport data (dashed grey line) is shown. Linear regression of passive transport is represented by the blue solid line. Data are shown as mean \pm SD of three independent experiments. 
Table 2. In vitro Organic Anion Transporter 1 (OAT1) kinetic parameters for indoxyl sulfate (IxS) and corresponding fraction unbound in incubation medium ( $\mathrm{fu}_{\mathrm{med}}$ ) in different human serum albumin (HSA) conditions investigated. IxS uptake was investigated in the absence of HSA (HSA-free), in the presence of HSA and in the presence of CKD-modified HSA. Values are presented as mean \pm SD of three independent experiments.

\begin{tabular}{|c|c|c|c|c|c|c|}
\hline $\begin{array}{c}\text { Albumin condition } \\
\text { used }\end{array}$ & $\begin{array}{c}\mathbf{V}_{\max } \\
\left(\mathrm{pmol} / \mathrm{min} / 10^{6} \mathrm{cells}\right)\end{array}$ & $\mathbf{K}_{\mathrm{m}}(\mu \mathrm{M})$ & $\mathbf{K}_{\mathrm{m}, \mathrm{u}}(\mu \mathrm{M})^{\mathbf{a}, \mathbf{b}}$ & IxS fu med & $\begin{array}{c}\text { IxS C } \mathbf{C L}_{\text {int,u }}{ }^{\mathbf{c}} \\
\left(\mu \mathrm{L} / \mathrm{min} / 10^{6} \text { cells }\right)\end{array}$ & $\begin{array}{c}\mathbf{C L}_{\text {int,u,scaled }}{ }^{\mathbf{d}, \mathbf{e , f}} \\
(\mathrm{mL} / \mathrm{min})\end{array}$ \\
\hline HSA-free & $26.5 \pm 2.2$ & $29.3 \pm 7.5$ & 29.3 & 1 & 0.90 & 9.2 \\
\hline$+\mathrm{HSA}$ & $48.1 \pm 2.5$ & $14.4 \pm 2.9$ & 1.4 & 0.1 & 33.7 & 342.5 \\
\hline +CKD-modified HSA & $27.7 \pm 1.0$ & $21.0 \pm 2.5$ & 5.4 & 0.26 & 5.1 & 52.0 \\
\hline
\end{tabular}

${ }^{a} K_{m}$ corrected by measured fumed $\left(K_{m}{ }^{*} f u_{m e d}=K_{m, u}\right)$. IxS fumed was 0.1 (albumin) and 0.26 in CKD-modified albumin condition

${ }^{b} K_{m, u}(\mu M)$ equivalent to 6.2 (HSA-free), $0.3(\mathrm{HSA})$ and $1.2 \mathrm{mg} / \mathrm{L}$ (CKD-modified HSA)

${ }^{c} \mathrm{CL}_{\text {int,u }}$ obtained as $\mathrm{V}_{\max } / \mathrm{K}_{\mathrm{m}, \mathrm{u}}$

dScaling factors used: REF $\mathrm{OATT}_{1}=1 ; \mathrm{PTCPGK}=60^{*} 10^{6}$ cells $/ \mathrm{g}$ kidney and $\mathrm{KW}_{\text {cortex }}=169 \mathrm{~g}$

eUsed as input in $\mathrm{CL}_{R}$ prediction model (eq. 5) in healthy subject population (HSA-free and HSA in vitro conditions) and in CKD stage IV population (CKD-modified HSA in vitro condition). Predicted $\mathrm{CL}_{\mathrm{R}}$ was 2 $9,11.0$ and $4.4 \mathrm{~mL} / \mathrm{min}$ for HSA-free, HSA and CKD-modified HSA, respectively.

fRelative contribution of OAT1-mediated active secretion clearance to $C L_{R}$ was $8.0,76$ and $70 \%$ for HSA-free, HSA and CKD-modified HSA, respectively. 
Albumin-facilitated indoxyl sulfate uptake via OAT1

Table 3. Studies reporting indoxyl sulfate fraction unbound in plasma ( $\left.I x S \mathrm{fu}_{\mathrm{p}}\right)$ in $\mathrm{CKD}$ patients and healthy subjects. Values in the studies were reported as median (interquartile range) or mean \pm SD. More detailed information on study characteristics (e.g. albumin levels, IxS detection method and time of sampling) can be found in Table S1 as well as additional studies only reporting IxS total concentrations. NR = not reported.

\begin{tabular}{|c|c|c|c|c|c|c|}
\hline Population & $\mathbf{n}$ & $\begin{array}{l}\text { Mean GFR } \\
\text { (mL/min) }\end{array}$ & $\begin{array}{l}\text { Serum IxS total } \\
\qquad(\mathrm{mg} / \mathrm{L})^{\mathrm{a}}\end{array}$ & $\begin{array}{l}\text { Serum IxS free } \\
\qquad(\mathrm{mg} / \mathrm{L})^{\mathrm{a}}\end{array}$ & IXS fup & Reference \\
\hline \multicolumn{7}{|l|}{ CKD patients } \\
\hline Prevalent hemodialysis patients & 1273 & NR & $25 \pm 12$ & $2.7 \pm 1.9$ & 0.11 & Shafi et al. ${ }^{50}$ \\
\hline Hemodialysis patients & 14 & NR & $19(10,23)$ & $1.3(0.6,1.7)$ & 0.07 & Camacho et al. ${ }^{51}$ \\
\hline $\begin{array}{l}\text { Patients with CKD stage IV or V } \\
\text { (nondialyzed) }\end{array}$ & 37 & $24 \pm 8$ & $3.8(2.6-5.8)$ & $0.15(0.09-0.2)$ & 0.04 & Rossi et al. ${ }^{52}$ \\
\hline Stable CKD patients on peritoneal dialysis & 15 & NR & $7.6 \pm 5.3$ & $0.7 \pm 0.4$ & 0.09 & Eloot et al. ${ }^{53}$ \\
\hline $\begin{array}{l}\text { Patients on initiation of maintenance dialysis } \\
\text { therapy in the preceding } 3 \text { months }\end{array}$ & 394 & NR & $17.1 \pm 10.2$ & $1.3 \pm 1.0$ & 0.07 & Shafi et al. ${ }^{54}$ \\
\hline Patients with varying stages of CKD & 327 & $46 \pm 25$ & $2.8(1.5-12.1)$ & $0.11(0.04-2.1)$ & 0.04 & Rossi et al. ${ }^{44}$ \\
\hline Patients on hemodialysis & 20 & NR & $35 \pm 9$ & $3.6 \pm 2.3$ & 0.10 & Sirich et al. ${ }^{55}$ \\
\hline
\end{tabular}


Albumin-facilitated indoxyl sulfate uptake via OAT1

\begin{tabular}{|c|c|c|c|c|c|c|}
\hline & \multirow[b]{2}{*}{20} & \multirow[b]{2}{*}{ NR } & \multirow[b]{2}{*}{$32 \pm 12$} & \multirow[b]{2}{*}{$2.8 \pm 1.6$} & \multirow[b]{2}{*}{0.09} & \\
\hline & & & & & & \\
\hline CKD stage $V$ not undergoing hemodialysis & 40 & $13 \pm 6$ & $11.6(10.9)$ & $1(1.23)$ & 0.09 & Wu et al. 56 \\
\hline Patients on peritoneal dialysis & 46 & NR & $41 \pm 16$ & $4.3 \pm 2.6$ & 0.11 & Lin et al. ${ }^{57}$ \\
\hline Uremic toxin workgroup & & & $37 \pm 27$ & $3.8 \pm 2.5$ & 0.10 & Eutox database ${ }^{58}$ \\
\hline Weighted mean advanced CKD & & & $24 \pm 13^{b}$ & $2.4 \pm 2.0^{\mathrm{b}}$ & 0.10 & \\
\hline \multicolumn{7}{|l|}{ Healthy subjects } \\
\hline Healthy subjects & 5 & $142 \pm 22$ & NR & $0.03 \pm 0.01$ & 0.03 & Sirich et al. 59 \\
\hline Healthy subjects & 42 & $93 \pm 12$ & $0.9(0.4-1.5)$ & $\begin{array}{c}0.02 \\
(0.02-0.02)\end{array}$ & 0.03 & Rossi et al. ${ }^{44}$ \\
\hline Healthy subjects & & & $0.54 \pm 4.0$ & & & Eutox database ${ }^{58}$ \\
\hline
\end{tabular}

a To convert value in $\mathrm{mg} / \mathrm{L}$ to $\mu \mathrm{M}$ for IxS: value $\mathrm{x}$ 1000/ 213 (molecular weight of IxS)

bStudies included in the weighted mean if subjects in the study had advanced stage of CKD (e.g., stage IV/V). In addition, if mean value \pm standard deviation was reported. 
Studies reporting indoxyl sulfate $C L_{R}$ in $C K D$ patients and healthy subjects. $A$ limited number of studies reporting actual IxS $C L_{R}$ was available (Table 4). Weighted mean of IxS $C L_{R}$ values reported in healthy subjects was $65 \pm 26 \mathrm{~mL} / \mathrm{min}$. Across a $C K D$ population, study average $C_{R}$ values ranged from 17.7-20.2 mL/min (Table 4). Average GFR values in these cohorts were 34.3 and $41.1 \mathrm{~mL} / \mathrm{min}$, respectively. Clinical IxS $\mathrm{CL}_{R}$ values for both healthy and advanced CKD (stage IV) for further analysis were taken from Poesen et al. ${ }^{47}$, since a correlation between a GFR range and IXS $C L_{R}$ was reported (e.g., $C L_{R}=0.67^{*} G F R-2.57, R^{2}=0.55$ ). This allowed calculation of $I X S C L_{R}$ for specific stages of CKD. Considering that CKD stage IV is defined by a GFR range of $15-30 \mathrm{~mL} / \mathrm{min}$, the midpoint of 22.5 $\mathrm{mL} / \mathrm{min}$ was used to calculate the corresponding $\mathrm{IxS} \mathrm{CL}_{\mathrm{R}}$ value $(12.5 \mathrm{~mL} / \mathrm{min})$ from linear regression. The average GFR taken for healthy subjects was $105 \mathrm{~mL} / \mathrm{min}$ (range 90-120), resulting in a calculated IXS $\mathrm{CL}_{\mathrm{R}}$ of $67.8 \mathrm{~mL} / \mathrm{min}$ for this population. 


\section{Albumin-facilitated indoxyl sulfate uptake via OAT1}

Table 4. Studies reporting indoxyl sulfate renal plasma excretion clearance (IxS $\left.C_{R}\right)$ in $C K D$ patients and healthy subjects. Values in the studies were reported as median (interquartile range) or mean $\pm \mathrm{SD}$. NR $=$ not reported.

\begin{tabular}{|c|c|c|c|c|c|c|c|}
\hline Population & $\mathbf{N}$ & $\begin{array}{l}\text { mean GFR } \\
\text { (mL/min) }\end{array}$ & $\begin{array}{l}\text { IxS CL } \\
\text { (mL/min) }\end{array}$ & $\begin{array}{c}\% \text { active renal } \\
\text { secretion }^{a}\end{array}$ & $\begin{array}{c}\text { Total serum } \\
\text { concentrations } \\
\text { of IxS (mg/mL) }\end{array}$ & IxS fup & Reference \\
\hline \multicolumn{8}{|l|}{ CKD patients } \\
\hline CKD patients (across all stages) & 291 & $\begin{array}{c}41.1 \\
(28.1-63.1)\end{array}$ & $\begin{array}{c}20.2 \\
(12.3-34.8)\end{array}$ & 88 & $3.2(1.9-4.9)$ & - & Suchy-Dicey et al. ${ }^{60}$ \\
\hline CKD patients (across all stages) & 203 & $\begin{array}{c}34.3 \\
(23.1-55.9)\end{array}$ & $\begin{array}{c}17.7 \\
(9.4-33.2)\end{array}$ & 88 & $2.04(1.09-4.0)$ & - & Poesen et al. ${ }^{47}$ \\
\hline GFR and $C L_{R}$ values used in this study & & 22.5 & $12.5^{b}$ & & & & \\
\hline \multicolumn{8}{|l|}{ Healthy subjects } \\
\hline Overweight, but otherwise healthy & 25 & $117 \pm 14$ & $67 \pm 28$ & 96 & $0.90 \pm 0.42$ & - & Rivara et al. ${ }^{61}$ \\
\hline Subjects with normal renal function & 5 & $142 \pm 22$ & $53 \pm 7$ & 93 & NR & 0.03 & Sirich et al. ${ }^{59}$ \\
\hline GFR and $C L_{R}$ values used in this study & & 105 & $67.8^{b}$ & & & & \\
\hline
\end{tabular}

${ }^{a}$ Active renal secretion clearance calculated as $\mathrm{CL}_{R}-\mathrm{fu}_{\mathrm{p}}{ }^{*} \mathrm{GFR}$. fup value of 0.025 was used for healthy subjects and 0.06 for $C K D$ stage IV patients.

${ }^{b}$ lxS $C_{R}$ calculated using correlation between GFR and IxS $\mathrm{CL}_{R}$ reported by Poesen et al. ${ }^{47}$ 
Albumin-facilitated indoxyl sulfate uptake via OAT1

\section{Quantitative translation of transporter in vitro data obtained in the presence and absence of}

albumin. In vitro OAT1-mediated uptake clearance of IxS obtained in absence or presence of HSA or CKD-modified HSA in the incubation medium was extrapolated to in vivo using the physiologicallybased approach (Eq. 4 and 5) (Table 2). Predicted $I x S C_{R}$ values in healthy subjects were 11.0 $\mathrm{mL} / \mathrm{min}$ and $2.9 \mathrm{~mL} / \mathrm{min}$ following translation of in vitro transporter data in presence of HSA versus absence of HSA, respectively.

Translation of in vitro OAT1-mediated $\mathrm{CL}_{\text {int,u }}$ obtained in CKD-modified albumin condition predicted a $60 \%$ decrease in IxS $\mathrm{CL}_{R}$ in $\mathrm{CKD}$ stage IV relative to healthy subjects. The predicted relative contribution of active secretion to IxS $\mathrm{CL}_{R}$ was $76 \%$ in healthy subjects and $70 \%$ in CKD stage IV (Table 2). Although translational method captured disease-related decrease in IxS $\mathrm{CL}_{R}$ reasonably well $\left(80 \%\right.$ decrease reported clinically $\left.{ }^{47}\right)$, it was apparent that absolute $I x S C_{R}$ values in both $C K D$ patients and healthy subjects were significantly under-predicted (observed $C_{R}$ is 12.5 and 67.8 $\mathrm{mL} / \mathrm{min}$, respectively, Table 4). In order to rationalise these trends and investigate the impact of uncertainty in some of the model input parameters on the predicted IXS $C L_{R}$, sensitivity analysis was performed (Table 5 , range of scaling factors explored is based on reported literature ${ }^{62-65}$ ). The analysis demonstrated sensitivity of the model to PTCPGK (range tested: $30-120 \times 10^{6}$, resulting in predicted $\mathrm{CL}_{R}$ of $6.9-19.2 \mathrm{~mL} / \mathrm{min}$ ) and $\mathrm{REF}_{\mathrm{OAT} 1}$ (range tested: $0.25-4$, resulting in predicted $\mathrm{CL}_{\mathrm{R}}$ of 4.8-34.8 $\mathrm{mL} / \mathrm{min}$ ). Due to lack of data, initial quantitative prediction of $\mathrm{CL}_{R}$ in $C K D$ assumed that these physiological scaling factors do not change with disease progression which is unlikely. Subsequent analysis where either number of proximal tubule cells or OAT1 expression (captured by REF $F_{\text {OAT1 }}$ ) were decreased proportionally to GFR (approximately 75\% in CKD stage IV) recovered clinically observed decrease in $\mathrm{CL}_{R}$ in advanced CKD patients relative to healthy (Table 6). 
Albumin-facilitated indoxyl sulfate uptake via OAT1

Table 5. Sensitivity analysis performed in healthy subjects to assess impact of uncertainty in

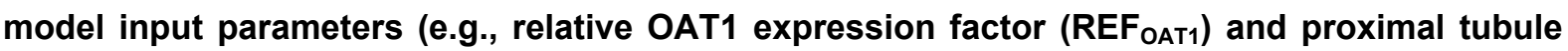
cells per $\mathbf{g}$ of kidney (PTCPGK)). Predictions were performed in healthy subjects after changes in systems parameters, using values of 1.00 (REF (RAT1 $_{1}$ ) and 60.0 (PTCPGK) as starting point. In these predictions, a range of 0.25-4 (REF OAT1 $_{\text {) }}$ and 30-120 $10^{6}$ cells/g kidney (PTCPGK) was explored. Remaining physiological system parameters used for prediction in healthy population are as defined in Table 1.

\begin{tabular}{|c|c|c|c|c|}
\hline $\begin{array}{c}\text { GFR } \\
(\mathrm{mL} / \mathrm{min})\end{array}$ & $\begin{array}{c}\text { REF OAT1 } \\
\text { (dimensionless) }\end{array}$ & $\begin{array}{c}\text { PTCPGK } \\
\left(10^{6} \text { cells/g kidney }\right)\end{array}$ & $\begin{array}{c}\text { IxS CL } \mathbf{C L}_{\text {int,u,scaled }} \\
(\mathrm{mL} / \mathrm{min})\end{array}$ & $\begin{array}{l}\text { IxS CL } \\
(\mathrm{mL} / \mathrm{min})\end{array}$ \\
\hline \multicolumn{5}{|c|}{ Sensitivity analysis in PTCPGK } \\
\hline 105 & 1 & 30 & 171 & 6.9 \\
\hline 105 & 1 & 40 & 228 & 8.3 \\
\hline 105 & 1 & 50 & 285 & 9.7 \\
\hline 105 & 1 & 60 & 343 & 11.0 \\
\hline 105 & 1 & 70 & 400 & 12.4 \\
\hline 105 & 1 & 80 & 457 & 13.8 \\
\hline 105 & 1 & 120 & 685 & 19.2 \\
\hline \multicolumn{5}{|c|}{ Sensitivity analysis in REF $\mathrm{OAT1}$} \\
\hline 105 & 0.25 & 60 & 86 & 4.8 \\
\hline 105 & 0.33 & 60 & 114 & 5.5 \\
\hline 105 & 0.5 & 60 & 171 & 6.9 \\
\hline 105 & 1 & 60 & 343 & 11.0 \\
\hline 105 & 2 & 60 & 685 & 19.2 \\
\hline 105 & 3 & 60 & 1027 & 27.1 \\
\hline 105 & 4 & 60 & 1370 & 34.8 \\
\hline
\end{tabular}


Albumin-facilitated indoxyl sulfate uptake via OAT1

Table 6. The impact of changes in physiologically-based scaling factors (REF OAT1 $_{1}$ or PTCPGK) in CKD population on predicted indoxyl sulfate renal plasma excretion clearance relative to healthy

\begin{tabular}{|cccccc|}
\hline GFR & REF $_{\text {OAT1 }}{ }^{a}$ & PTCPGKa & IxS & IxS CL & Predicted decrease in $\mathrm{CL}_{\mathrm{R}}$ \\
& & $\mathrm{CL}_{\text {int,u,scaled }}$ & & in CKD relative to healthy \\
\hline$(\mathrm{mL} / \mathrm{min})$ & & $\begin{array}{c}\left(10^{6} \text { cells/g }\right. \\
\text { kidney })\end{array}$ & $(\mathrm{mL} / \mathrm{min})$ & $(\mathrm{mL} / \mathrm{min})$ & 60 \\
\hline 22.5 & 1.00 & 60.0 & 52.0 & 4.4 & 81 \\
\hline 22.5 & $0.25(75 \%)$ & 60.0 & 13.0 & 2.1 & 81 \\
\hline 22.5 & 1.00 & $15.0(75 \%)$ & 13.0 & 2.1 & \\
\hline
\end{tabular}

alf shown, number in brackets represents decrease in the scaling factor in CKD population relative to healthy. Remaining physiological system parameters used for prediction in CKD are as defined in Table 1.

Transepithelial transport of indoxyl sulfate in ciPTEC-OAT1. To assess the ability of microfluidic system to capture physiological complexities of CKD, IxS transepithelial transport was investigated upon perfusion with plasma from renal healthy controls spiked with IxS $(282 \mu \mathrm{M})$ or plasma from CKD patients with the same IxS concentration (as measured). Transepithelial transport of IxS across ciPTEC-OAT1 monolayers was evident in all conditions (Figure 3), with unaltered cell viability and barrier function (Figure S2). A 55\% reduction in transepithelial transport rate was observed in the presence of uremic plasma compared to plasma from renal healthy controls spiked with IxS (2270 \pm 700 vs. $4140 \pm 320 \mathrm{pmol} / \mathrm{min} / 10^{6}$ cells, Figure 3 ). Transepithelial transport decreased (>85\%) by coperfusion with probenecid. 


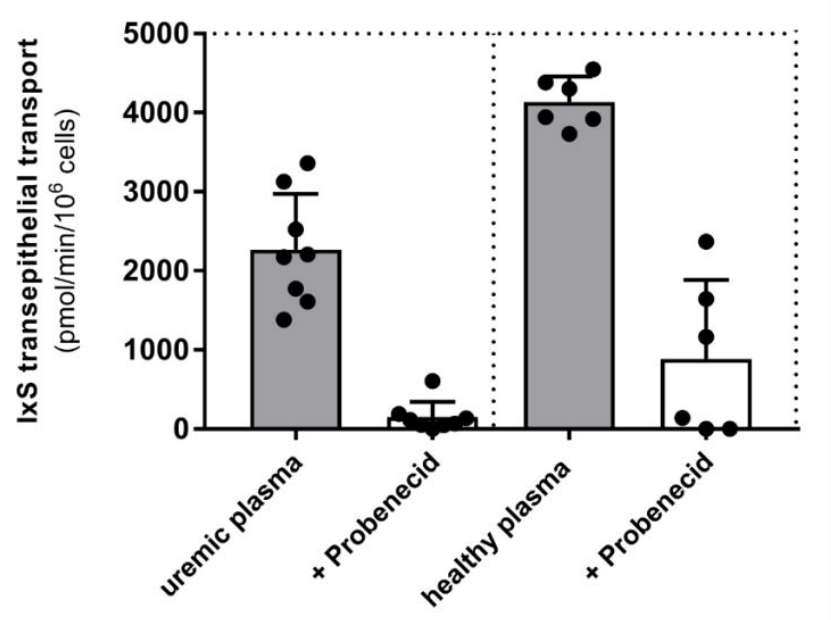

Figure 3. Active secretion of indoxyl sulfate (IxS) in ciPTEC-OAT1 cells in the microfluidic system exposed to either healthy plasma or uremic plasma. Panel on the left illustrates the experimental design to determine IxS transepithelial transport in the microfluidic system $(E C M=$ extracellular matrix). ciPTEC-OAT1 were perfused with human plasma samples for 10 min at flow rate of $6 \mathrm{~mL} . \mathrm{h}^{-1}$. The panel on the right depicts transepithelial transport of IxS when incubated in the presence of uremic plasma $(282 \pm 4 \mu \mathrm{M})$ or healthy plasma spiked with IxS $(282 \mu \mathrm{M})$ in the absence or presence of probenecid $(500 \mu \mathrm{M})$. Data are shown as mean \pm SD of at least three independent experiments (performed in duplicate). High variability between individual experiments was evident and may be related to inconsistency in barrier integrity in different experiments. In addition, the efficacy of probenecid in the basolateral compartment may have been affected in presence of certain plasma samples, for unknown reasons. 
Albumin-facilitated indoxyl sulfate uptake via OAT1

\section{DISCUSSION}

The concept of albumin-facilitated drug transport has been postulated and rationalised by the presence of membrane "albumin receptors" that facilitate uptake of highly albumin-bound drugs in hepatocytes. $^{66-68}$ Recently, a similar mechanism has been proposed for uptake via renal OAT transporters. ${ }^{11,} 18$ Clinical data in CKD patients report increased IXS accumulation and reduced extent of IxS binding to albumin in this population. ${ }^{15}$ However, potential role of albumin-facilitated OAT1 transport in either healthy or CKD subjects and its effect on IxS $C L_{R}$ is not understood. To this end, the impact of albumin (either healthy or CKD-modified) in cell culture medium on active IxS secretion via OAT1 was studied in a novel microfluidic system. To increase clinical relevance of generated in vitro data, a quantitative physiologically-based translational approach was applied to predict the extent of change in IxS $C_{R}$ in CKD relative to the healthy population. IxS was selected as a compound of interest due availability of clinical data in both populations, its high extent of binding to albumin in healthy subjects and the fact that active secretion via OATs contributes predominantly to its renal excretion.

In vitro data on active IXS uptake to ciPTEC-OAT1 showed augmented transporter affinity in the presence of albumin compared to albumin-free condition (Table 2). Increased IxS OAT1 $\mathrm{CL}_{\text {int,u }}$ was attributed not only to higher IXS affinity for OAT1, but also to increased maximum transporter rates in HSA condition. One possibility is that albumin facilitates access to transporter binding site by overcoming the electrochemical barrier, especially for organic anions. Literature evidence supporting albumin-facilitated transport has mainly focused on hepatic drug transporters. ${ }^{66,} 69-71$ Albuminfacilitated active transport observed here for IxS indicates relevance of this mechanism for renal OAT1 transporter, but additional mechanistic studies and inclusion of a wider range of drugs (e.g., ranging in fraction bound to albumin, fraction actively secreted by proximal tubule etc.) are required.

In addition to reduced plasma albumin concentration, CKD is also associated with post-translational guanidinylation of albumin. ${ }^{15}$ Guanidinylation appears to cause conformational change in albumin and was proposed as explanation for lower extent of IxS binding to albumin isolated from CKD patients compared to albumin from healthy controls. Rueth et al. ${ }^{15}$ suggested that the impact of additional unknown post-translational modifications on binding capacity of albumin in CKD patients might be 
Albumin-facilitated indoxyl sulfate uptake via OAT1

low. Therefore, CKD-modified albumin synthesised with only guanidinylation post-translational modification in albumin was used in the current study. Our in vitro data showed decreased affinity of unbound IxS for OAT1, and a reduction in overall OAT1-mediated uptake $\mathrm{CL}_{\text {int,u }}$ in the presence of CKD-modified HSA compared to unmodified albumin. Measuring and accounting for IxS binding in different albumin conditions was crucial to avoid bias in interpretation of transporter binding affinity, as illustrated by 4 -fold increase in unbound $\mathrm{K}_{\mathrm{m}}$ in CKD-modified HSA relative to HSA condition (Table 2), in contrast to marginal change in uncorrected $\mathrm{K}_{\mathrm{m}}$ under the same conditions. Current findings imply that both binding and/or alteration in albumin-facilitating transport are contributing to decreased IxS uptake via OAT1 in CKD. One possibility is that albumin modification in CKD results in reduced binding capacity but stronger binding to albumin compared to healthy condition. ${ }^{15}$

Quantitative translation of IxS in vitro unbound intrinsic clearance represents the first application of this approach for the transporter kinetic data generated in microfluidic system. IVIVE of data obtained in albumin or CKD-modified albumin condition predicted the observed relative decrease in $C L_{R}$ in CKD stage IV compared to renal healthy subjects. In the first instance, REF OAT1 and PTCPGK physiological scaling factors were kept the same for both healthy and CKD due to lack of quantitative data on these scalars. To address the $20 \%$ discrepancy between predicted and observed changes in IxS $\mathrm{CL}_{\mathrm{R}}$, reduction in $\mathrm{REF}_{\mathrm{OAT1}}$ and PTCPGK as a result of disease was explored in the model. The transporter protein expression $\left(\mathrm{REF}_{\mathrm{OAT} 1}\right)$ or tubular cellularity (PTCPGK) were reduced proportional to changes in GFR, in line with the intact nephron hypothesis (Table 6). This approach resulted in excellent agreement between predicted decrease in IxS $C L_{R}$ in $C K D$ and the clinical observations.

Although the translational approach captured relative decrease in IxS $C L_{R}$ well, it was apparent that absolute $C L_{R}$ values in both healthy controls and CKD patients were significantly under-predicted. This under-prediction trend has been reported previously for translation of both hepatic and renal transporter kinetic data.40, 69, 72 In the current study, contribution of OAT3 to IxS uptake was not taken into account. The affinity of IxS for OAT3 is 7-10-fold lower relative to OAT19, 10 and therefore lack of consideration of OAT3 is not anticipated to be a major contributor to the under-prediction trend noted. Existing knowledge gaps and/or uncertainty in some of the renal physiological parameters and scaling factors, in particular for CKD population, hamper accurate prediction of mechanistic renal drug 
Albumin-facilitated indoxyl sulfate uptake via OAT1

disposition. ${ }^{25,} 29,31$ The analysis performed here highlighted sensitivity of the $\mathrm{CL}_{R}$ prediction model to both REF $_{\mathrm{OAT} 1}$ and PTCPGK values emphasizing the need for accurate determination of these physiological scaling factors for specific patient populations like CKD. Current evidence and data on absolute OAT1 protein abundance in healthy subjects is limited to few studies ${ }^{73-75}$ whereas no OAT1 protein expression data are reported in CKD patients. The importance of determination of OAT1 protein abundance in cell lines used in the microfluidic system to inform the REF scalar is also emphasized.

Evaluation of predictive performance of the in vitro data generated in the microfluidic system is also affected by the quality of available in vivo data used for comparison. High intra- and inter-variability in total/free IXS concentrations was evident in CKD patient groups with similar severity of disease (Table 3, S1). This variability may reflect differing diets, the inflammatory microenvironment and gut microbiota which may impact IxS production ${ }^{76}$, but may also be related to IxS detection methods used. ${ }^{77}$ Ideally, clinical studies should report plasma $\mathrm{IXS} \mathrm{CL}_{R}$ in healthy subjects and in specific CKD stages, together with data on the free fractions of IxS in plasma. Especially considering that relatively small changes in total concentration of a tightly bound ligand may result in large fluctuations in the free fraction. ${ }^{78}$

In addition to quantitative translational efforts, preliminary studies were performed to mimic complex interplay between uremic solutes and changes in albumin in CKD. ciPTEC-OAT1 cells were perfused with plasma from renal healthy control spiked with IXS or plasma isolated from CKD patients to assess potential combined effects of multiple uremic solutes present in CKD and albumin modifications on OAT1 transporter activity. The preliminary transepithelial transport data showed ability of the microfluidic system to capture reduced overall IxS secretion in uremic plasma relative to renal healthy controls. Further mechanistic studies are required to delineate the impact of individual mechanisms and to investigate quantitative translation of such data. Quantitative translation of transepithelial transport data is not well established at this stage due to lack of adequate mechanistic data and corresponding scaling factors. 
Albumin-facilitated indoxyl sulfate uptake via OAT1

In conclusion, the findings of the current study support the hypothesis of albumin-facilitated active transport via OAT1. As such, inclusion of albumin in physiologic concentrations is recommended for in vitro OAT1 assays, particularly for highly albumin-bound compounds. In addition, current findings highlight the impact of modifications of plasma albumin on active transport of IxS via OAT1 in vitro. For the first time, this study applied quantitative translation of transporter kinetic data generated in a novel microfluidic system to a clinically relevant setting and identified important knowledge gaps required for quantitative prediction of renal drug disposition. We envisage that the application of novel microfluidic systems together with mechanistic modelling of in vitro data will significantly increase our understanding of underlying processes responsible for the accumulation of uremic toxins and provide valuable input in PBPK models to support model-informed dose recommendations for this patient population. 


\section{ASSOCIATED CONTENT}

Supporting information

Figure S1. Determination of indoxyl sulfate (IxS) fraction unbound in incubation media ( $\left.\mathrm{fu}_{\mathrm{med}}\right)$ in the presence of human serum albumin (HSA) and CKD-modified HSA.

Figure S2. Cell viability and barrier function upon perfusion with uremic plasma, healthy plasma and healthy plasma spiked with IxS (282 $\mu \mathrm{M})$.

Table S1. Studies (after 2012) reporting serum indoxyl sulfate (IxS) free and total concentrations and fraction unbound in plasma $\left(\mathrm{fu}_{\mathrm{p}}\right)$ in $\mathrm{CKD}$ patients and healthy subjects.

Table S2. Determination of average cell number per fiber $(n=6)$.

Table S3. Reported differences in $Q_{R}$ parameter between healthy subjects and CKD patients.

Supplementary Methods. LC/MS analysis of indoxyl sulfate samples

\section{ACKNOWLEDGEMENTS}

T.vdM. is supported by a PhD studentship funded by Janssen Pharmaceutica NV, Beerse, Belgium. This research was funded by the Marie Curie ITN project BIOART (grant no. 316690, EU-FP7PEOPLE-ITN-2012). Further, this study was supported by the ERA-EDTA endorsed Work Group EUTox and by a grant by the German Research Foundation (DFG)(SFB/TRR219 S-03 (V.J.), C-04 (J.J.), IHST 948/4S-1 FU6.6).

\section{ABBREVIATIONS}

ciPTEC-OAT1, conditionally immortalized human proximal tubule cells overexpressing OAT1; $\mathrm{CL}_{\text {int,u, }}$ in vitro unbound intrinsic clearance; $\mathrm{CL}_{\text {int,u,scaled }}$, scaled in vivo unbound intrinsic clearance; $\mathrm{CL}_{R}$, renal plasma excretion clearance; CKD, chronic kidney disease; $F_{\text {reab }}$, fractional tubular reabsorption; $\mathrm{fu}_{\text {med }} / \mathrm{fu}_{\mathrm{p}}$, fraction unbound in media/plasma; HSA, human serum albumin; IVIVE, in vitro- in vivo extrapolation; IxS, indoxyl sulfate; $\mathrm{K}_{\mathrm{m}, \mathrm{u}}$, unbound transporter affinity; $\mathrm{KW}_{\text {cortex }}$, kidney cortex weight; OAT1, organic anion transporter 1; PBPK, physiologically-based pharmacokinetic modelling; 
PTCPGK, proximal tubule cells per $g$ of kidney; $Q_{R}$, renal cortex blood flow; $R_{B: P}$, blood-to-plasma ratio; $R E F$, relative expression factor; $V_{\max }$, maximum uptake rate

\section{REFERENCES}

1. Bruck, K.; Stel, V. S.; Gambaro, G.; Hallan, S.; Volzke, H.; Arnlov, J.; Kastarinen, M.; Guessous, I.; Vinhas, J.; Stengel, B.; Brenner, H.; Chudek, J.; Romundstad, S.; Tomson, C.; Gonzalez, A. O.; Bello, A. K.; Ferrieres, J.; Palmieri, L.; Browne, G.; Capuano, V.; Van Biesen, W.; Zoccali, C.; Gansevoort, R.; Navis, G.; Rothenbacher, D.; Ferraro, P. M.; Nitsch, D.; Wanner, C.; Jager, K. J. CKD Prevalence Varies across the European General Population. J. Am. Soc. Nephrol. 2016, 27, (7), 2135-47.

2. United States Renal Data System, 2018 USRDS Annual data report. Chapter 1 - CKD in the general population. National Institutes of Health, National Institute of Diabetes and Digestive and Kidney Diseases, Bethesda, MD: https://www.usrds.org/adr.aspx, 2018; Vol. Volume 1: CKD in the United States.

3. Hsueh, C. H.; Yoshida, K.; Zhao, P.; Meyer, T. W.; Zhang, L.; Huang, S. M.; Giacomini, K. M. Identification and Quantitative Assessment of Uremic Solutes as Inhibitors of Renal Organic Anion Transporters, OAT1 and OAT3. Mol. Pharm. 2016, 13, (9), 3130-40.

4. Vanholder, R.; Schepers, E.; Pletinck, A.; Nagler, E. V.; Glorieux, G. The uremic toxicity of indoxyl sulfate and p-cresyl sulfate: a systematic review. J. Am. Soc. Nephrol. 2014, 25, (9), $1897-$ 907.

5. Leong, S. C.; Sirich, T. L. Indoxyl Sulfate-Review of Toxicity and Therapeutic Strategies. Toxins (Basel) 2016, 8, (12).

6. $\quad$ Bricker, N. S.; Morrin, P. A.; Kime, S. W., Jr. The pathologic physiology of chronic Bright's disease. An exposition of the "intact nephron hypothesis". Am. J. Med. 1960, 28, 77-98.

7. Naud, J.; Michaud, J.; Beauchemin, S.; Hebert, M. J.; Roger, M.; Lefrancois, S.; Leblond, F. A.; Pichette, V. Effects of chronic renal failure on kidney drug transporters and cytochrome P450 in rats. Drug Metab. Dispos. 2011, 39, (8), 1363-9.

8. Watanabe, H.; Miyamoto, Y.; Otagiri, M.; Maruyama, T. Update on the pharmacokinetics and redox properties of protein-bound uremic toxins. J. Pharm. Sci. 2011, 100, (9), 3682-95.

9. $\quad$ Enomoto, A.; Takeda, M.; Tojo, A.; Sekine, T.; Cha, S. H.; Khamdang, S.; Takayama, F.; Aoyama, I.; Nakamura, S.; Endou, H.; Niwa, T. Role of organic anion transporters in the tubular transport of indoxyl sulfate and the induction of its nephrotoxicity. J. Am. Soc. Nephrol. 2002, 13, (7), $1711-20$.

10. Deguchi, T.; Kusuhara, H.; Takadate, A.; Endou, H.; Otagiri, M.; Sugiyama, Y. Characterization of uremic toxin transport by organic anion transporters in the kidney. Kidney Int. 2004, 65, (1), 162-74.

11. Jansen, J.; Fedecostante, M.; Wilmer, M. J.; Peters, J. G.; Kreuser, U. M.; van den Broek, P. H.; Mensink, R. A.; Boltje, T. J.; Stamatialis, D.; Wetzels, J. F.; van den Heuvel, L. P.; Hoenderop, J. G.; Masereeuw, R. Bioengineered kidney tubules efficiently excrete uremic toxins. Sci. Rep. 2016, 6, 26715.

12. Mutsaers, H. A.; van den Heuvel, L. P.; Ringens, L. H.; Dankers, A. C.; Russel, F. G.; Wetzels, J. F.; Hoenderop, J. G.; Masereeuw, R. Uremic toxins inhibit transport by breast cancer resistance protein and multidrug resistance protein 4 at clinically relevant concentrations. PLoS One 2011, 6, (4), e18438.

13. Enomoto, A.; Takeda, M.; Taki, K.; Takayama, F.; Noshiro, R.; Niwa, T.; Endou, H. Interactions of human organic anion as well as cation transporters with indoxyl sulfate. Eur. J. Pharmacol. 2003, 466, (1-2), 13-20.

14. Viaene, L.; Annaert, P.; de Loor, H.; Poesen, R.; Evenepoel, P.; Meijers, B. Albumin is the main plasma binding protein for indoxyl sulfate and p-cresyl sulfate. Biopharm. Drug Dispos. 2013, 34, (3), 165-75.

15. Rueth, M.; Lemke, H. D.; Preisinger, C.; Krieter, D.; Theelen, W.; Gajjala, P.; Devine, E.; Zidek, W.; Jankowski, J.; Jankowski, V. Guanidinylations of albumin decreased binding capacity of hydrophobic metabolites. Acta Physiol (Oxf) 2015, 215, (1), 13-23.

16. Jansen, J.; Jankowski, J.; Gajjala, P. R.; Wetzels, J. F. M.; Masereeuw, R. Disposition and clinical implications of protein-bound uremic toxins. Clin. Sci. (Lond.) 2017, 131, (14), 1631-1647. 17. Gajjala, P. R.; Fliser, D.; Speer, T.; Jankowski, V.; Jankowski, J. Emerging role of posttranslational modifications in chronic kidney disease and cardiovascular disease. Nephrol. Dial. Transplant. 2015, 30, (11), 1814-24. 
18. Pichette, V.; Geadah, D.; du Souich, P. Role of plasma protein binding on renal metabolism and dynamics of furosemide in the rabbit. Drug Metab. Dispos. 1999, 27, (1), 81-5.

19. Jansen, J.; De Napoli, I. E.; Fedecostante, M.; Schophuizen, C. M.; Chevtchik, N. V.; Wilmer, M. J.; van Asbeck, A. H.; Croes, H. J.; Pertijs, J. C.; Wetzels, J. F.; Hilbrands, L. B.; van den Heuvel, L. P.; Hoenderop, J. G.; Stamatialis, D.; Masereeuw, R. Human proximal tubule epithelial cells cultured on hollow fibers: living membranes that actively transport organic cations. Sci. Rep. 2015, 5, 16702.

20. Jones, H. M.; Barton, H. A.; Lai, Y.; Bi, Y. A.; Kimoto, E.; Kempshall, S.; Tate, S. C.; ElKattan, A.; Houston, J. B.; Galetin, A.; Fenner, K. S. Mechanistic pharmacokinetic modeling for the prediction of transporter-mediated disposition in humans from sandwich culture human hepatocyte data. Drug Metab. Dispos. 2012, 40, (5), 1007-17.

21. Rostami-Hodjegan, A. Physiologically based pharmacokinetics joined with in vitro-in vivo extrapolation of ADME: a marriage under the arch of systems pharmacology. Clin. Pharmacol. Ther. 2012, 92, (1), 50-61.

22. Guo, Y.; Chu, X.; Parrott, N. J.; Brouwer, K. L. R.; Hsu, V.; Nagar, S.; Matsson, P.; Sharma, P.; Snoeys, J.; Sugiyama, Y.; Tatosian, D.; Unadkat, J. D.; Huang, S. M.; Galetin, A.; International Transporter, C. Advancing Predictions of Tissue and Intracellular Drug Concentrations Using In Vitro, Imaging and Physiologically Based Pharmacokinetic Modeling Approaches. Clin Pharmacol Ther 2018, 104, (5), 865-889.

23. Gertz, M.; Cartwright, C. M.; Hobbs, M. J.; Kenworthy, K. E.; Rowland, M.; Houston, J. B.; Galetin, A. Cyclosporine inhibition of hepatic and intestinal CYP3A4, uptake and efflux transporters: application of PBPK modeling in the assessment of drug-drug interaction potential. Pharm. Res. 2013, 30, (3), 761-80.

24. Badee, J.; Achour, B.; Rostami-Hodjegan, A.; Galetin, A. Meta-analysis of expression of hepatic organic anion-transporting polypeptide (OATP) transporters in cellular systems relative to human liver tissue. Drug Metab. Dispos. 2015, 43, (4), 424-32.

25. Scotcher, D.; Jones, C.; Posada, M.; Rostami-Hodjegan, A.; Galetin, A. Key to Opening Kidney for In Vitro-In Vivo Extrapolation Entrance in Health and Disease: Part I: In Vitro Systems and Physiological Data. Aaps j 2016, 18, (5), 1067-81.

26. Tsamandouras, N.; Chen, W. L. K.; Edington, C. D.; Stokes, C. L.; Griffith, L. G.; Cirit, M. Integrated Gut and Liver Microphysiological Systems for Quantitative In Vitro Pharmacokinetic Studies. Aaps j 2017, 19, (5), 1499-1512.

27. Cirit, M.; Stokes, C. L. Maximizing the impact of microphysiological systems with in vitro-in vivo translation. Lab Chip 2018, 18, (13), 1831-1837.

28. Galetin, A.; Zhao, P.; Huang, S. M. Physiologically Based Pharmacokinetic Modeling of Drug Transporters to Facilitate Individualized Dose Prediction. J. Pharm. Sci. 2017, 106, (9), 2204-2208. 29. Grimstein, M.; Yang, Y.; Zhang, X.; Grillo, J.; Huang, S. M.; Zineh, I.; Wang, Y. Physiologically Based Pharmacokinetic Modeling in Regulatory Science: An Update From the U.S. Food and Drug Administration's Office of Clinical Pharmacology. J. Pharm. Sci. 2019, 108, (1), 21-25. 30. Tan, M. L.; Zhao, P.; Zhang, L.; Ho, Y. F.; Varma, M. V. S.; Neuhoff, S.; Nolin, T. D. Use of Physiologically Based Pharmacokinetic Modeling to Evaluate the Effect of Chronic Kidney Disease on the Disposition of Hepatic CYP2C8 and OATP1B Drug Substrates. 2019, 105, (3), 719-729.

31. Scotcher, D.; Jones, C. R.; Galetin, A.; Rostami-Hodjegan, A. Delineating the Role of Various Factors in Renal Disposition of Digoxin through Application of Physiologically Based Kidney Model to Renal Impairment Populations. J. Pharmacol. Exp. Ther. 2017, 360, (3), 484-495.

32. Hsu, V.; de, L. T. V. M.; Zhao, P.; Zhang, L.; Zheng, J. H.; Nordmark, A.; Berglund, E. G.; Giacomini, K. M.; Huang, S. M. Towards quantitation of the effects of renal impairment and probenecid inhibition on kidney uptake and efflux transporters, using physiologically based pharmacokinetic modelling and simulations. Clin. Pharmacokinet. 2014, 53, (3), 283-293. 33. Hsueh, C. H.; Hsu, V.; Zhao, P.; Zhang, L.; Giacomini, K. M.; Huang, S. M. PBPK Modeling of the Effect of Reduced Kidney Function on the Pharmacokinetics of Drugs Excreted Renally by Organic Anion Transporters. Clin. Pharmacol. Ther. 2018, 103, (3), 485-492.

34. Nieskens, T. T.; Peters, J. G.; Schreurs, M. J.; Smits, N.; Woestenenk, R.; Jansen, K.; van der Made, T. K.; Roring, M.; Hilgendorf, C.; Wilmer, M. J.; Masereeuw, R. A Human Renal Proximal Tubule Cell Line with Stable Organic Anion Transporter 1 and 3 Expression Predictive for AntiviralInduced Toxicity. Aaps j 2016, 18, (2), 465-75.

35. Jansen, J.; Schophuizen, C. M.; Wilmer, M. J.; Lahham, S. H.; Mutsaers, H. A.; Wetzels, J. F.; Bank, R. A.; van den Heuvel, L. P.; Hoenderop, J. G.; Masereeuw, R. A morphological and functional comparison of proximal tubule cell lines established from human urine and kidney tissue. Exp. Cell Res. 2014, 323, (1), 87-99. 
36. Neuhoff, S.; Gaohua, L.; Burt, H.; Jamei, M.; Li, L.; Tucker, G.; Rostami-Hodjegan, A., Accounting for Transporters in Renal Clearance: Towards a Mechanistic Kidney Model (Mech KiM). In Transporters in Drug Development. Discovery, Optimization, Clinical Study and Regulation, Steffansen, Y. S. B., Ed. Springer Science+Business Media: New York, 2013; pp p. 155-77. 37. Habu, Y.; Yano, I.; Takeuchi, A.; Saito, H.; Okuda, M.; Fukatsu, A.; Inui, K. Decreased activity of basolateral organic ion transports in hyperuricemic rat kidney: roles of organic ion transporters, rOAT1, rOAT3 and rOCT2. Biochem. Pharmacol. 2003, 66, (6), 1107-14.

38. Forbes, M. S.; Thornhill, B. A.; Minor, J. J.; Gordon, K. A.; Galarreta, C. I.; Chevalier, R. L. Fight-or-flight: murine unilateral ureteral obstruction causes extensive proximal tubular degeneration, collecting duct dilatation, and minimal fibrosis. Am. J. Physiol. Renal Physiol. 2012, 303, (1), F120-9. 39. Deguchi, T.; Takemoto, M.; Uehara, N.; Lindup, W. E.; Suenaga, A.; Otagiri, M. Renal clearance of endogenous hippurate correlates with expression levels of renal organic anion transporters in uremic rats. J. Pharmacol. Exp. Ther. 2005, 314, (2), 932-8.

40. Zamek-Gliszczynski, M. J.; Lee, C. A.; Poirier, A.; Bentz, J.; Chu, X.; Ellens, H.; Ishikawa, T.; Jamei, M.; Kalvass, J. C.; Nagar, S.; Pang, K. S.; Korzekwa, K.; Swaan, P. W.; Taub, M. E.; Zhao, P.; Galetin, A. ITC recommendations for transporter kinetic parameter estimation and translational modeling of transport-mediated PK and DDIs in humans. Clin. Pharmacol. Ther. 2013, 94, (1), 64-79. 41. Yang, J.; Jamei, M.; Yeo, K. R.; Rostami-Hodjegan, A.; Tucker, G. T. Misuse of the wellstirred model of hepatic drug clearance. Drug Metab. Dispos. 2007, 35, (3), 501-2.

42. Rowland Yeo, K.; Aarabi, M.; Jamei, M.; Rostami-Hodjegan, A. Modeling and predicting drug pharmacokinetics in patients with renal impairment. Expert Rev. Clin. Pharmacol. 2011, 4, (2), 26174.

43. Duranton, F.; Cohen, G.; De Smet, R.; Rodriguez, M.; Jankowski, J.; Vanholder, R.; Argiles, A. Normal and pathologic concentrations of uremic toxins. J. Am. Soc. Nephrol. 2012, 23, (7), 125870.

44. Rossi, M.; Campbell, K.; Johnson, D.; Stanton, T.; Pascoe, E.; Hawley, C.; Dimeski, G.; McWhinney, B.; Ungerer, J.; Isbel, N. Uraemic toxins and cardiovascular disease across the chronic kidney disease spectrum: an observational study. Nutr. Metab. Cardiovasc. Dis. 2014, 24, (9), 103542.

45. Molina, D. K.; DiMaio, V. J. Normal organ weights in men: part II-the brain, lungs, liver, spleen, and kidneys. Am. J. Forensic Med. Pathol. 2012, 33, (4), 368-72.

46. Molina, D. K.; DiMaio, V. J. Normal Organ Weights in Women: Part II-The Brain, Lungs, Liver, Spleen, and Kidneys. Am. J. Forensic Med. Pathol. 2015, 36, (3), 182-7.

47. Poesen, R.; Viaene, L.; Verbeke, K.; Claes, K.; Bammens, B.; Sprangers, B.; Naesens, M.; Vanrenterghem, Y.; Kuypers, D.; Evenepoel, P.; Meijers, B. Renal clearance and intestinal generation of p-cresyl sulfate and indoxyl sulfate in CKD. Clin. J. Am. Soc. Nephrol. 2013, 8, (9), 1508-14.

48. Scotcher, D.; Billington, S.; Brown, J.; Jones, C. R.; Brown, C. D. A.; Rostami-Hodjegan, A.; Galetin, A. Microsomal and Cytosolic Scaling Factors in Dog and Human Kidney Cortex and Application for In Vitro-In Vivo Extrapolation of Renal Metabolic Clearance. Drug Metab. Dispos. 2017, 45, (5), 556-568.

49. Chapter 1: Definition and classification of CKD. Kidney Int Suppl (2011) 2013, 3, (1), 19-62. 50. Shafi, T.; Sirich, T. L.; Meyer, T. W.; Hostetter, T. H.; Plummer, N. S.; Hwang, S.; Melamed, M. L.; Banerjee, T.; Coresh, J.; Powe, N. R. Results of the HEMO Study suggest that p-cresol sulfate and indoxyl sulfate are not associated with cardiovascular outcomes. Kidney Int. 2017, 92, (6), 14841492.

51. Camacho, O.; Rosales, M. C.; Shafi, T.; Fullman, J.; Plummer, N. S.; Meyer, T. W.; Sirich, T. $\mathrm{L}$. Effect of a sustained difference in hemodialytic clearance on the plasma levels of $p$-cresol sulfate and indoxyl sulfate. Nephrol. Dial. Transplant. 2016, 31, (8), 1335-41.

52. Rossi, M.; Johnson, D. W.; Morrison, M.; Pascoe, E. M.; Coombes, J. S.; Forbes, J. M.; Szeto, C. C.; McWhinney, B. C.; Ungerer, J. P.; Campbell, K. L. Synbiotics Easing Renal Failure by Improving Gut Microbiology (SYNERGY): A Randomized Trial. Clin. J. Am. Soc. Nephrol. 2016, 11, (2), 223-31.

53. Eloot, S.; Vanholder, R.; Dequidt, C.; Van Biesen, W. Removal of Different Classes of Uremic Toxins in APD vs CAPD: A Randomized Cross-Over Study. Perit. Dial. Int. 2015, 35, (4), 436-42.

54. Shafi, T.; Meyer, T. W.; Hostetter, T. H.; Melamed, M. L.; Parekh, R. S.; Hwang, S.; Banerjee, T.; Coresh, J.; Powe, N. R. Free Levels of Selected Organic Solutes and Cardiovascular Morbidity and Mortality in Hemodialysis Patients: Results from the Retained Organic Solutes and Clinical Outcomes (ROSCO) Investigators. PLoS One 2015, 10, (5), e0126048. 
55. Sirich, T. L.; Plummer, N. S.; Gardner, C. D.; Hostetter, T. H.; Meyer, T. W. Effect of increasing dietary fiber on plasma levels of colon-derived solutes in hemodialysis patients. Clin. J. Am. Soc. Nephrol. 2014, 9, (9), 1603-10.

56. Wu, I. W.; Hsu, K. H.; Sun, C. Y.; Tsai, C. J.; Wu, M. S.; Lee, C. C. Oral adsorbent AST-120 potentiates the effect of erythropoietin-stimulating agents on Stage 5 chronic kidney disease patients: a randomized crossover study. Nephrol. Dial. Transplant. 2014, 29, (9), 1719-27.

57. Lin, C. J.; Pan, C. F.; Chuang, C. K.; Liu, H. L.; Sun, F. J.; Wang, T. J.; Chen, H. H.; Wu, C. J. Gastrointestinal-related uremic toxins in peritoneal dialysis: a pilot study with a 5-year follow-up. Arch. Med. Res. 2013, 44, (7), 535-41.

58. The European Uremic Toxins Database, Available online at www.uremic-toxins.org. Accessed on $16 / 05 / 2019$.

59. Sirich, T. L.; Aronov, P. A.; Plummer, N. S.; Hostetter, T. H.; Meyer, T. W. Numerous proteinbound solutes are cleared by the kidney with high efficiency. Kidney Int. 2013, 84, (3), 585-90.

60. Suchy-Dicey, A. M.; Laha, T.; Hoofnagle, A.; Newitt, R.; Sirich, T. L.; Meyer, T. W.; Thummel, K. E.; Yanez, N. D.; Himmelfarb, J.; Weiss, N. S.; Kestenbaum, B. R. Tubular Secretion in CKD. J. Am. Soc. Nephrol. 2016, 27, (7), 2148-55.

61. Rivara, M. B.; Zelnick, L. R.; Hoofnagle, A. N.; Newitt, R.; Tracy, R. P.; Kratz, M.; Weigle, D. S.; Kestenbaum, B. R. Diurnal and Long-term Variation in Plasma Concentrations and Renal Clearances of Circulating Markers of Kidney Proximal Tubular Secretion. Clin. Chem. 2017, 63, (4), 915-923.

62. Posada, M. M.; Cannady, E. A.; Payne, C. D.; Zhang, X.; Bacon, J. A.; Pak, Y. A.; Higgins, J. W.; Shahri, N.; Hall, S. D.; Hillgren, K. M. Prediction of Transporter-Mediated Drug-Drug Interactions for Baricitinib. Clin. Transl. Sci. 2017, 10, (6), 509-519.

63. Ball, K.; Jamier, T.; Parmentier, Y.; Denizot, C.; Mallier, A.; Chenel, M. Prediction of renal transporter-mediated drug-drug interactions for a drug which is an OAT substrate and inhibitor using PBPK modelling. Eur. J. Pharm. Sci. 2017, 106, 122-132.

64. Mathialagan, S.; Piotrowski, M. A.; Tess, D. A.; Feng, B.; Litchfield, J.; Varma, M. V. Quantitative Prediction of Human Renal Clearance and Drug-Drug Interactions of Organic Anion Transporter Substrates Using In Vitro Transport Data: A Relative Activity Factor Approach. Drug Metab. Dispos. 2017, 45, (4), 409-417.

65. Feng, B.; Hurst, S.; Lu, Y.; Varma, M. V.; Rotter, C. J.; El-Kattan, A.; Lockwood, P.; Corrigan, B. Quantitative prediction of renal transporter-mediated clinical drug-drug interactions. Mol. Pharm. 2013, 10, (11), 4207-15.

66. Weisiger, R.; Gollan, J.; Ockner, R. Receptor for albumin on the liver cell surface may mediate uptake of fatty acids and other albumin-bound substances. Science 1981, 211, (4486), 104851.

67. Mao, J.; Mohutsky, M. A.; Harrelson, J. P.; Wrighton, S. A.; Hall, S. D. Predictions of cytochrome P450-mediated drug-drug interactions using cryopreserved human hepatocytes: comparison of plasma and protein-free media incubation conditions. Drug Metab. Dispos. 2012, 40, (4), 706-16.

68. Wilkinson, G. R. Clearance approaches in pharmacology. Pharmacol. Rev. 1987, 39, (1), 1-

47.

69. Kim, S. J.; Lee, K. R.; Miyauchi, S.; Sugiyama, Y. Extrapolation of In Vivo Hepatic Clearance from In Vitro Uptake Clearance by Suspended Human Hepatocytes for Anionic Drugs with High Binding to Human Albumin: Improvement of In Vitro-to-In Vivo Extrapolation by Considering the "Albumin-Mediated" Hepatic Uptake Mechanism on the Basis of the "Facilitated-Dissociation Model". Drug Metab. Dispos. 2019, 47, (2), 94-103.

70. Poulin, P.; Haddad, S. Extrapolation of the Hepatic Clearance of Drugs in the Absence of Albumin In Vitro to That in the Presence of Albumin In Vivo: Comparative Assessement of 2 Extrapolation Models Based on the Albumin-Mediated Hepatic Uptake Theory and Limitations and Mechanistic Insights. J. Pharm. Sci. 2018, 107, (7), 1791-1797.

71. Miyauchi, S.; Masuda, M.; Kim, S. J.; Tanaka, Y.; Lee, K. R.; Iwakado, S.; Nemoto, M.; Sasaki, S.; Shimono, K.; Tanaka, Y.; Sugiyama, Y. The Phenomenon of Albumin-Mediated Hepatic Uptake of Organic Anion Transport Polypeptide Substrates: Prediction of the In Vivo Uptake Clearance from the In Vitro Uptake by Isolated Hepatocytes Using a Facilitated-Dissociation Model. Drug Metab. Dispos. 2018, 46, (3), 259-267.

72. Menochet, K.; Kenworthy, K. E.; Houston, J. B.; Galetin, A. Use of mechanistic modeling to assess interindividual variability and interspecies differences in active uptake in human and rat hepatocytes. Drug Metab. Dispos. 2012, 40, (9), 1744-56. 
73. Basit, A.; Radi, Z.; Vaidya, V. S.; Karasu, M.; Prasad, B. Kidney Cortical Transporter Expression across Species Using Quantitative Proteomics. Drug Metab. Dispos. 2019, 47, (8), 802808.

74. Li, C. Y.; Hosey-Cojocari, C.; Basit, A.; Unadkat, J. D.; Leeder, J. S.; Prasad, B. Optimized Renal Transporter Quantification by Using Aquaporin 1 and Aquaporin 2 as Anatomical Markers: Application in Characterizing the Ontogeny of Renal Transporters and Its Correlation with Hepatic Transporters in Paired Human Samples. Aaps j 2019, 21, (5), 88.

75. Cheung, K. W. K.; van Groen, B. D.; Spaans, E.; van Borselen, M. D.; de Bruijn, A.; SimonsOosterhuis, Y.; Tibboel, D.; Samsom, J. N.; Verdijk, R. M.; Smeets, B.; Zhang, L.; Huang, S. M.; Giacomini, K. M.; de Wildt, S. N. A Comprehensive Analysis of Ontogeny of Renal Drug Transporters: mRNA Analyses, Quantitative Proteomics, and Localization. Clin. Pharmacol. Ther. 2019.

76. Evenepoel, P.; Poesen, R.; Meijers, B. The gut-kidney axis. Pediatr. Nephrol. 2017, 32, (11), 2005-2014.

77. Evenepoel, P.; Glorieux, G.; Meijers, B. p-cresol sulfate and indoxyl sulfate: some clouds are gathering in the uremic toxin sky. Kidney Int. 2017, 92, (6), 1323-1324.

78. Meijers, B. K.; Bammens, B.; Verbeke, K.; Evenepoel, P. A review of albumin binding in CKD. Am. J. Kidney Dis. 2008, 51, (5), 839-50. 